\section{Modeling and mapping soil resistance to penetration and rutting using LiDAR- derived digital elevation data}

\author{
D.M.H. Campbell, B. White, and P.A. Arp
}

\begin{abstract}
Soil resistances to penetration were probed with a hand-held soil cone penetrometer across ridge-to-depression transects for two contrasting study areas in Alberta, Canada: one in the foothills west of Calgary, and one in the boreal plain north of Peace River. The resulting cone index values (CI) were related to plot-measured values for soil moisture, density, texture, organic matter content, soil depth, elevation, slope, and a cartographic depth-to-water index (DTW) by way of multiple regression analysis. Elevation, slope, DTW, and the associated flow accumulation pattern were all derived from a light detection and ranging (LiDAR)-generated bare ground digital elevation model (DEM), at $1 \mathrm{~m}(3 \mathrm{ft})$ resolution. The field-determined CI values conformed to a previous formulation that related CI to soil texture, density, and waterfilled pore space. In terms of topographic position, CI increased with increasing DTW, in parallel with decreasing soil moisture content and increasing soil density. The resulting best-fitted regression between $\mathrm{CI}, \log _{10}(\mathrm{DTW})$, and elevation (or study area) was used to map CI and expected all-terrain recreational vehicle-specific rutting depths across the landscape. The maps so generated were in general agreement with the results of a $40 \mathrm{~km}(25 \mathrm{mi})$ long soil disturbance survey along a recreational vehicle trail section within the foothill area.
\end{abstract}

Key words: cartographic depth-to-water index-digital elevation model-light detection and ranging — recreational vehicle trails — rut depth—soil resistance to penetration

Forecasting soil trafficability is an important aspect of regulating on- and off-road recreational, agricultural, and industrial activities across landscapes because uncontrolled traffic leads to considerable soil degradation in terms of rutting, compaction, and erosion (McNabb et al. 1985, Wilson and Seney 1994, Horn 2004; Saarilahti 2002; Eliasson 2005; Foltz 2006; Nahdi et al. 2009). Soils, once degraded, lead to inefficiencies in field operations, subsequent reductions in crop production, unnecessary release of sediments and pollutants to surface water, unsightly postoperational aesthetics, unsafe working conditions, and increasingly negative public perceptions (Rab et al. 2005; Raper 2005; Zenner 2007; Stokowski and Lapointe 2000; Marion and Olive 2006; Wilkerson and Whitman 2009). Soil rutting is of concern because ruts reduce soil pore space, injure and cut roots, interfere with new root growth, obstruct natural flow paths, produce

stagnant water pools, and initiate gulley formation and washouts along slopes (Carter et al. 2000, 2007; Blouin et al. 2005; Foltz 2006). Activities intended to curb negative soil disturbance effects refer to (1) seasonally imposed rules and regulations for on- and off-road vehicular transport, (2) adherence to agreed upon best management practices and related certification requirements with respect to minmizing soil disturbances, and (3) follow up in terms of quality control by way of soil disturbance monitoring and best management practice effectiveness evaluations, recommendations, and guidelines (Duckert et al. 2008; Miller et al. 2010). Impact controlling activities involve, for example, proactively reducing the severity (length, depth, and frequency) of rutting through operations timing; placing gravel, boards, cords, brush, or mats, including geosynthetics, along trails (Grenier et al. 2008); and prohibiting road and trail use during wet weather conditions.
This article focuses on determining soil resistances to penetration (or soil penetrability) as primary means to model and map soil trafficability in general, and soil rutting specifically. The analytical framework to do this was derived from the Waterways Experiment Station Method of the US Army Engineers (Carter et al. 2000, Saarilahti 2002; Priddy and Willoughby 2006). This method uses cone penetrometers (1) to probe the resistance of soils to penetration, (2) to ascertain how many vehicles of certain type and load can pass through an area under given soil and weather conditions without exceeding a predefined rutting depth, and (3) to evaluate the effect of rutting on soil compaction and strength. In general, soil penetrability increases with increasing sand and moisture content, but it typically decreases with increasing clay content (Nearing 1988) and increasing soil depth due to increasing soil densities (Rooney 2008; McNabb et al. 1985). Wronski et al. (1990), Landsberg et al. (2003), Agodzo (2003), and Saarilahti and Antilla (1999) reported similar results. VegaNieva et al. (2009) noted that soils are less resistant to penetration under reconstituted laboratory conditions than under field conditions, i.e., $\mathrm{CI}_{\mathrm{lab}}=1.14 \times 10^{3.99-1.36 \text { Sand }-6.6 \mathrm{PS}-1.20 \mathrm{MCPS}} ;$
$r^{2}=0.77$

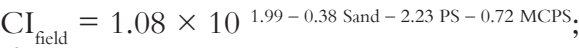
$r^{2} \stackrel{\text { field }}{=} 0.87$, where CI is the cone index for soil penetrability up to $\approx 7 \mathrm{MPa}$, Sand is sand fraction of the fine-earth fraction with particle size $<2 \mathrm{~mm}(<0.08 \mathrm{in})$, PS is the pore space fraction, and MCPS is the water-filled fraction of PS. Hence, equation 2 can, at least in principle, be used to estimate CI based on existing soil survey reports that inform about soil texture, density, and specific moisture conditions by soil type. CI mapping by soil

David M.H. Campbell is a research assistant in the Faculty of Forestry and Environmental Management, University of New Brunswick, Fredericton, New Brunswick, Canada. Barry White is a provincial forest management specialist in the Alberta Sustainable Resource Department, Edmonton, Alberta, Canada. Paul A. Arp is a professor of forest soils in the Faculty of Forestry and Environmental Management, University of New Brunswick, Fredericton, New Brunswick, Canada. 
type, however, would be coarse and assumes uniform conditions within each soil polygon. In reality, soil moisture conditions vary significantly by topographic position, depth-to-water (DTW) towards slopes away from open-water surfaces and channels, and antecedent to current weather conditions. Similarly, soil depth, texture, organic matter (OM) content, and densities also tend to vary by topographic position, with soils generally being shallower, coarser, denser, and less enriched with OM along steep slopes and upland positions than in depressions (Murphy et al. 2011). The objectives of this article address these variations

1. by determining how changes in soil CI can be related to (a) changing soil texture, moisture, density, and OM content and (b) changing topographic position and DTW in particular through multiple regression analysis;

2 . by using the resulting best-fitted regression models for CI to map soil penetrability and CI-inferred off-road rutting potentials according to landscape position from ridge top to depressions; and

3. by comparing the results of a trail damage survey along a recreational vehicle trail with the CI-determined map for potential off-road soil rutting.

The main hypothesis is that soil trafficability and rutting can be modeled and mapped by terrain conditions (bulk density, texture, and soil moisture regime) across the landscape. In detail, objective 1 involved sampling soil penetration and properties along ridge-to-depression transects representing two contrasting forest areas in Alberta, Canada (figure 1): the forested foothills west of Calgary (Ghost River Forest Land Use Zone [GRFLUZ]) (GRFLUZ 2012; Ghost River Alliance 2011), and an area within the boreal plain of Northern Alberta (Ecosystem Management Emulating Natural Disturbance [EMEND]) (EMEND 2012) northwest of Peace River. Objective 2 involved spatial analyses pertaining to (1) modelling and mapping soil CI and rutting potential using a digital elevation model (DEM) and (2) deriving DEM attributes pertaining to elevation, slope, surface roughness, flow direction, flow accumulation, flow-channel networks, and flow-channel referenced DTW (Murphy et al. 2011). Objective 3 involved classifying the severity of trail damage along a $40 \mathrm{~km}$ (25 mi) recreational vehicle track within the GRFLUZ area and analyzing the same by overlaying on the maps generated by way of objective 2 .

\section{Materials and Methods}

Study Sites. The GRFLUZ area west of Calgary (51ำ $19^{\prime} 59^{\prime \prime} \mathrm{N}, 114^{\circ} 57^{\prime} 59^{\prime \prime} \mathrm{W}$; area $=113,000$ ha $[280,000 \mathrm{ac}])$ has elevations ranging from 1,190 to $2,590 \mathrm{~m}(3,904$ to $8,497 \mathrm{ft}$ ) above sea level. The EMEND area $\left(56^{\circ} 46^{\prime} 13^{\prime \prime} \mathrm{N}, 118^{\circ} 22^{\prime} 28^{\prime \prime} \mathrm{W}\right.$; area $=1,800$ ha [4,448 ac]) has elevations from 633 to $887 \mathrm{~m}$ (2,077 to $2,910 \mathrm{ft}$ ) above sea level. These areas receive 540 and $431 \mathrm{~mm}$ (21 and $17 \mathrm{in}$ ) of precipitation on average per year, with mean annual air temperatures at $2^{\circ} \mathrm{C}$ and $1.2^{\circ} \mathrm{C}$ $\left(36^{\circ} \mathrm{F}\right.$ and $\left.34^{\circ} \mathrm{F}\right)$, mean January temperatures at $-10^{\circ} \mathrm{C}$ and $-17.7^{\circ} \mathrm{C}\left(14^{\circ} \mathrm{F}\right.$ and $\left.0^{\circ} \mathrm{F}\right)$, and mean July temperatures at $13^{\circ} \mathrm{C}$ and $15.9^{\circ} \mathrm{C}$ $\left(55^{\circ} \mathrm{F}\right.$ and $\left.61^{\circ} \mathrm{F}\right)$, respectively. The bedrock at GRFLUZ belongs to the Brazeau, Coalspur, and Paskapoo formations, mainly consisting of Cretaceous Age sandstones, shales and siltstone, overlain by alluvial, colluvial or glacial deposits. GRFLUZ soils are dominated by Grey Luvisols (Alfisols) interspersed by Brunisols (Entisols). The forest vegetation consists of lodgepole pine (Pinus contorta) white spruce (Picea glauca), and black spruce (Picea mariana) as dominant species. The bedrock at EMEND is comprised of unconsolidated and bentonitic Lower and Upper Cretaceous deposits containing sandstones and shales (Bayrock 1958). These are overlain by generally fine-textured till, interspersed by organic and alluvial materials (Kishuk 2004). EMEND soils are dominated by Gray Luvisols or Brunisols (Alfisols or Entisols) with pockets of Luvic Gleysols and Solonetzs (Alfisols and Vertisols). EMEND vegetation is typically dominated by trembling aspen (Populus tremuloides), balsam fir (Abies balsamea), and white spruce.

Digital Elevation Data Processing. The light detection and ranging (LiDAR)-based digital elevation data for bare ground were obtained for both study areas from the Research Information Branch of the Alberta Government, as acquired and provided by Airborne Imaging Inc. (Calgary, Alberta), using Airborne Laser Scanning software to identify and classify ground returns as subset of the last returns. These data had a vertical accuracy of about $\pm 15 \mathrm{~cm}$ ( $\pm 5.9 \mathrm{in}$ ) for open conditions such as road surfaces, and were converted into a $1 \mathrm{~m}(3 \mathrm{ft})$ digital elevation model, i.e., or DEM. This model was used to generate the following data layers for each study area, using ESRI ArcGIS (ArcMap 9.3) software (ESRI, Redlands, California): 1. slope;
2. flow direction (D8 algorithm) after filling all DEM depressions;

3. flow accumulation;

4. flow-channel networks with 4 and 1 ha (10 and $2.5 \mathrm{ac}$ ) for flow initiation thresholds; and

5. the cartographically determined DTW layer associated with each flow network, using the methods described by Murphy et al. (2009, 2011; White et al. 2012).

In brief, DTW corresponds to the least elevational difference between any point in the landscape and the nearest open water locations as marked by flow channels, lakes, and shorelines where DTW is set equal to 0 .

Transects. Transect sampling was done at both locations in reference to the DEMgenerated DTW map, from low to high, as shown in figures 2 and 3. At EMEND, this sampling involved 4 transect locations producing a total of 82 plots (5 m [16 ft] radius each), each replicated 3 times. At GRFLUZ, sampling involved 7 transect locations with a total of 97 plots, also replicated 3 times. Sampling occurred from July to August of 2009 (EMEND) and from mid-July to mid-August of 2010 (GRFLUZ). All plots were geographically registered using global positioning system (GPS) technology (Magellan MobileMapper 6, $5 \mathrm{~m}$ resolution). For each plot,

1. soil cores (5 to $40 \mathrm{~cm}$ [ 1 to $16 \mathrm{in}$ ] deep; $1.78 \mathrm{~cm}$ [0.7 in] diameter) were collected and aggregated to yield at least $100 \mathrm{~g} \mathrm{(3.5}$ oz) of soil for texture and chemical analyses;

2. the depths of organic horizons on top of the mineral soil layers and the soil core depth below the forest floor were measured;

3. soil layer type was recorded;

4. the soil resistance to cone penetration

(CI) was determined with a hand-held cone penetrometer (Humboldt HS-4210; cone angle $=60^{\circ}$; diameter at cone base $=1.53 \mathrm{~cm}$ [0.6 in]; penetrometer length $50 \mathrm{~cm}$ [19.7 in]; maximum supported load: 7.6 MPa); CI values were recorded at $5 \mathrm{~cm}$ (2 in) soil depth intervals until reaching the manually attainable penetration maximum $\left(\mathrm{CI}_{\max }\right)$; and

5. the volumetric soil moisture content $\left(\mathrm{MCv}_{\text {field }}\right)$ was determined for the top $10 \mathrm{~cm}$ (3.9 in) of the mineral soil using a time domain reflectance probe (Theta Moisture Probe).

The CI and $\mathrm{MCv}_{\text {field }}$ measurements were repeated 5 times and averaged for each plot. CI was recorded at $5 \mathrm{~cm}$ (1 in) depth increments up to the maximum attainable value $\left(\mathrm{CI}_{\max }\right)$. 


\section{Figure 1}

Locator map for the Ghost River Forest Land Use Zone (GRFLUZ) and Ecosystem Management Emulating Natural Disturbance (EMEND) study areas in Alberta, Canada, with inserts showing transect locations, GRFLUZ trail survey area (white rectangle), roads, seismic lines, lakes, and light detection and ranging-digital elevation model (LIDAR-DEM) derived hill-shaded elevation.

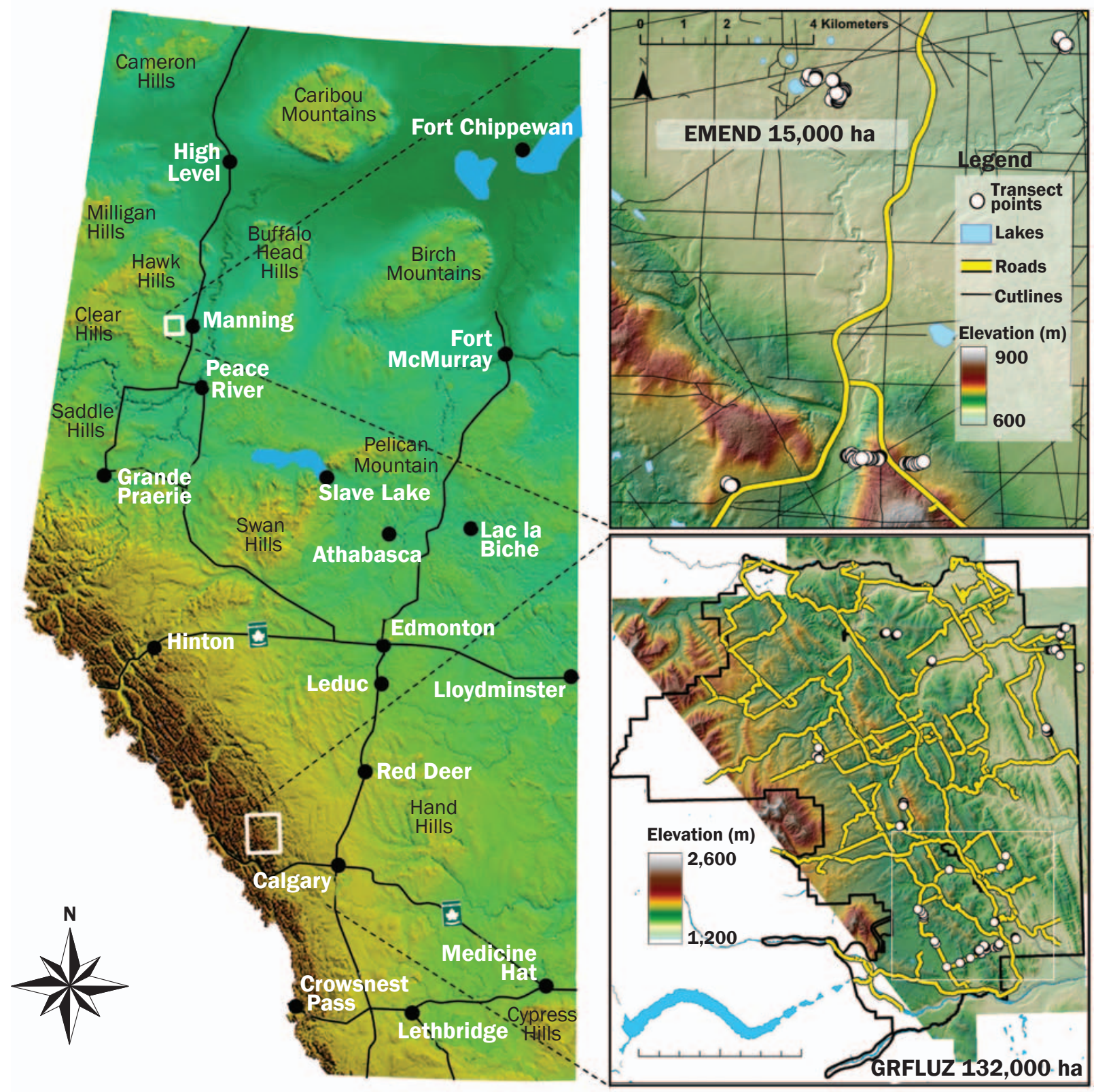

Typically, soil penetration resistance increased with increasing soil depth. Maximum penetration pressure, however, was limited by (1) the upper body weight of the sampler, and (2) a general inability to maintain a constant penetration velocity with increasing soil resistance. Typically, the $\mathrm{CI}_{\text {max }}$ values so generated were more consistent per plot than the CI values at any soil depth.

Soil Analysis. The aggregated soil core samples were placed into plot-labeled freezer bags, kept cool during transport, and dried at $75^{\circ} \mathrm{C}\left(167^{\circ} \mathrm{F}\right)$ for 24 hours. Following the instructions by McKeague (1978), the dried aggregates were then crushed, and the fine-earth fraction was separated from coarse materials through sieving (2 mm [0.08 in]). The fractions separated in this way were weighed to estimate the coarse fragment content (CF) within each sample. The sedimentation method was used to determine the sand, silt, and clay proportions within each of the sieved samples $(50 \mathrm{~g}$ [1.8 oz]). Soil carbon (C) was determined using the LECO CNS-
2000 , using $500 \mathrm{mg}(0.018 \mathrm{oz})$ portion of the sieved soil. Soil OM was estimated by setting $\mathrm{OM}=1.7 \mathrm{C}$. The gravimetric soil moisture $\left(\mathrm{MC}_{\mathrm{g}}\right)$ was determined as part of the soil drying process. $\mathrm{MC}_{\mathrm{g}}$ was then converted into volumetric soil moisture $\left(\mathrm{MC}_{\mathrm{v}}\right)$ and waterfilled pore space (MCPS) based on soil particle density (Dp), soil bulk density (Db) and pore space (PS) estimates as described below (equations 3 through 6; Balland et al. 2008).

Soil Attribute Derivations, including Potential Rutting Depth. The soil property 


\section{Figure 2}

(a) Transect locations within the Ecosystem Management Emulating Natural Disturbance (EMEND) study area overlaid on hill-shaded digital elevation model and the cartographic depth-to-water overlaid as it varies from o to $1 \mathrm{~m}$ (blue shading from dark to light, respectively) along flow channels and lakes. (b) Close ups on the transect location, also showing roads and seismic lines.

(a)

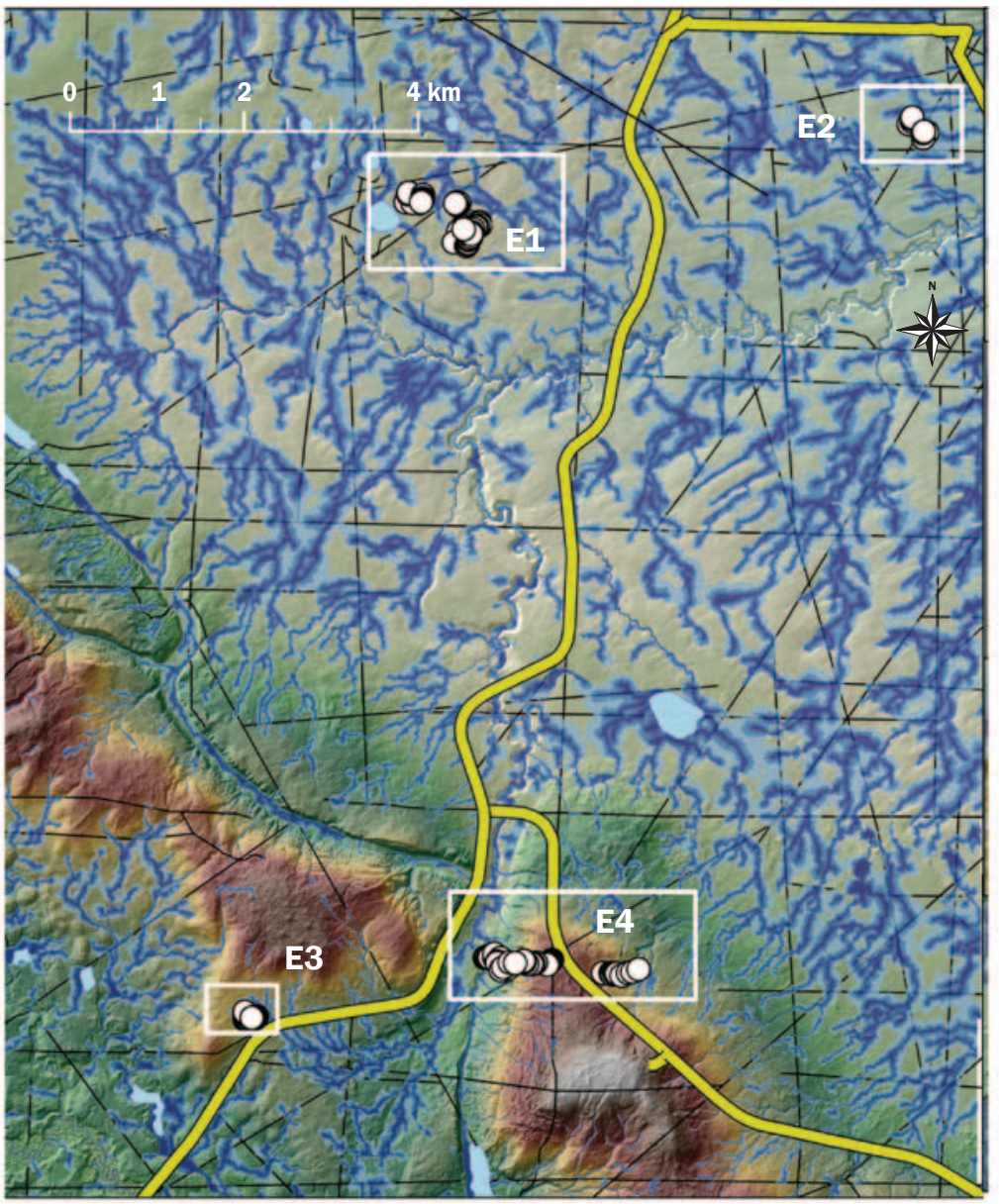

(b)

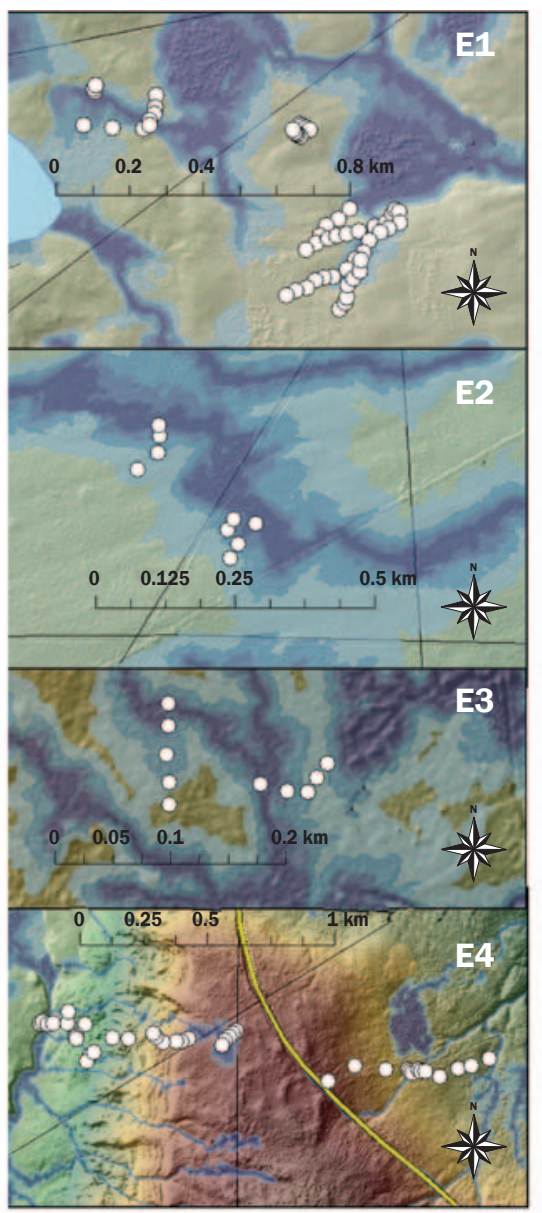

data were examined and checked for quality. Missing or erroneous data were omitted. The resulting dataset was processed in several ways:

1. The average soil properties for sand, silt, clay, OM, Db, Dp, PS, $\mathrm{MC}_{\mathrm{g}}, \mathrm{MC}_{\mathrm{v}}$, and MCPS were determined and compiled for each aggregated soil sample.

2. The sample-generated Sand, OM, and soil depth were used to infer Db, Dp, PS and MCPS for the field condition (Balland et al. 2006) as follows:

$$
\begin{aligned}
& \mathrm{Db}_{\text {field }}=\frac{1.23+(\mathrm{Dp}-1.23-0.75 \text { Sand })[1-\exp (-0.0106 \text { Depth })],(3)}{1+6.83 \mathrm{OM}} \\
& 1 \div \mathrm{Dp}_{\text {field }}=\mathrm{OM} \div \mathrm{D}_{\text {om }}+(1-\mathrm{OM}) \div \mathrm{D}_{\text {min }}, \text { (4) } \\
& \mathrm{PS}_{\text {field }}=1-\mathrm{Db}_{\text {field }} \div \mathrm{Dp}_{\text {field }},
\end{aligned}
$$

and
$\mathrm{MCPS}_{\text {field }}=\mathrm{MCv}_{\text {field }} \div \mathrm{PS}_{\text {field }}$,

with $\mathrm{D}_{\mathrm{OM}}=1.3 \mathrm{~g} \mathrm{~cm}^{-3}\left(0.0578 \mathrm{lb} \mathrm{in}^{-3}\right)$ and $\mathrm{D}_{\min }=2.65 \mathrm{~g} \mathrm{~cm}^{-3}\left(0.0957 \mathrm{lb} \mathrm{in}^{-3}\right)$ as the particle densities of $\mathrm{OM}$ and mineral soil, respectively.

3. CI values were related to equation 2 based on the sample-determined values for Sand, PS, and MCPS; the fieldestimated values for $\mathrm{Db}_{\text {field }}, \mathrm{PS}_{\text {field }}$, and MCPS $_{\text {field }}$; and the soil depth.

4. $\mathrm{CI}_{\text {max }}, \mathrm{Db}_{\text {field }}, \mathrm{PS}_{\text {field }}$, and MCPS $\mathrm{Mield}_{\text {fere }}$ prorated to $10 \mathrm{~cm}$ (3.9 in) soil depth and the resulting values were related to elevation, slope, terrain wetness index (TWI) and $\log _{10}$ (DTW) by way of regression analysis. Subsequently the resulting best-fitted regression model was used for estimating $\mathrm{CI}_{\max }$ and $\mathrm{CI}$ at $10 \mathrm{~cm}$ (4 in) depth.
5. Potential rut depths were inferred from (Saarilahti 2002; Vega-Nieva et al. 2009)

$\mathrm{Z}_{\mathrm{n}}=(1,656 \div \mathrm{NCI}) \mathrm{n}^{1 / 2}$,

with NCI as normalized CI given by

$\mathrm{NCI}=\mathrm{CI}(b d \div W)(\delta \div h)^{0.5} \div(1+b \div 2 d)$,

where $b$ is tire width $(\mathrm{m}), d$ is tire diameter $(\mathrm{m}), h$ is section height $(\mathrm{m}), \delta$ is tire deflection $(\mathrm{m})$ and given by $0.008+0.001$ $(0.365+170 \div p), p$ is tire inflation pressure $(\mathrm{kPa}), W$ is vehicle load $(\mathrm{kN}$ per number of wheels), and $n$ is number of vehicle passes along the same track.

6. Potential rutting depths of all-terrain recreational vehicle (ATVs)-generated rut depths were determined, using the estimated CI values at $10 \mathrm{~cm}$ soil depth and setting: $\mathrm{W}=$ weight + load $=3.1 \mathrm{kN} ; b=0.254 \mathrm{~m}$ 


\section{Figure 3}

(a) Transect locations within the Ghost River Forest Land Use Zone (GRFLUZ) area with LiDAR-derived digital elevation model (hill-shaded) plus the depth-to-water index (DTW) from o to $1 \mathrm{~m}$ (blue shading from dark to light, respectively) along flow channels and lakes and existing trails and roads (yellow). (b) Close ups for the Ghost River Forest Land Use Zone (GRFLUZ) transect locations.

(a)

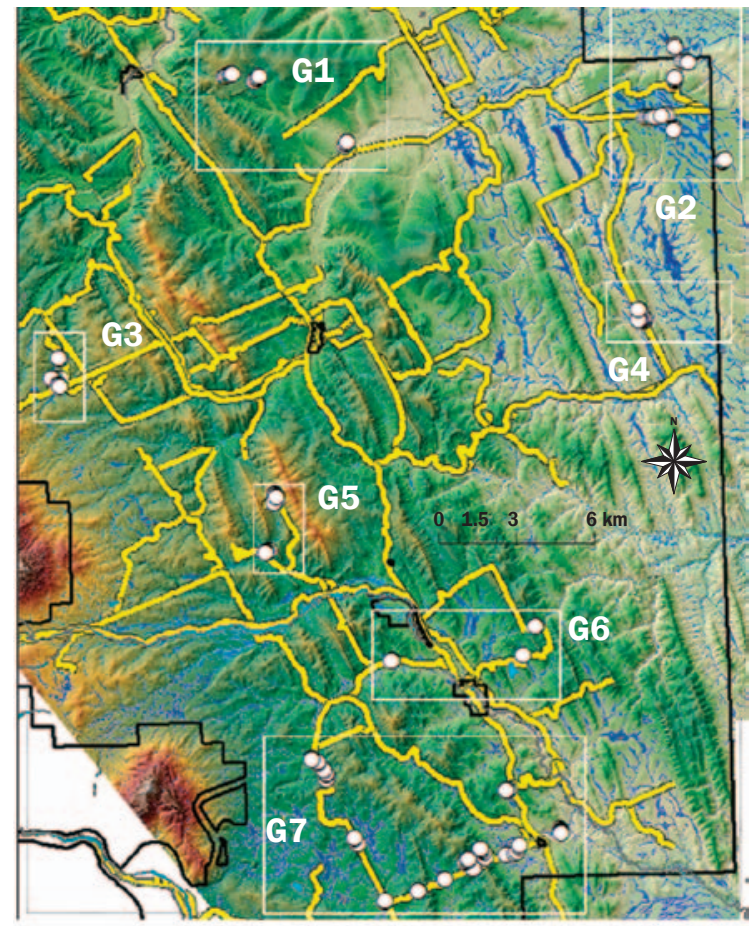

(b)

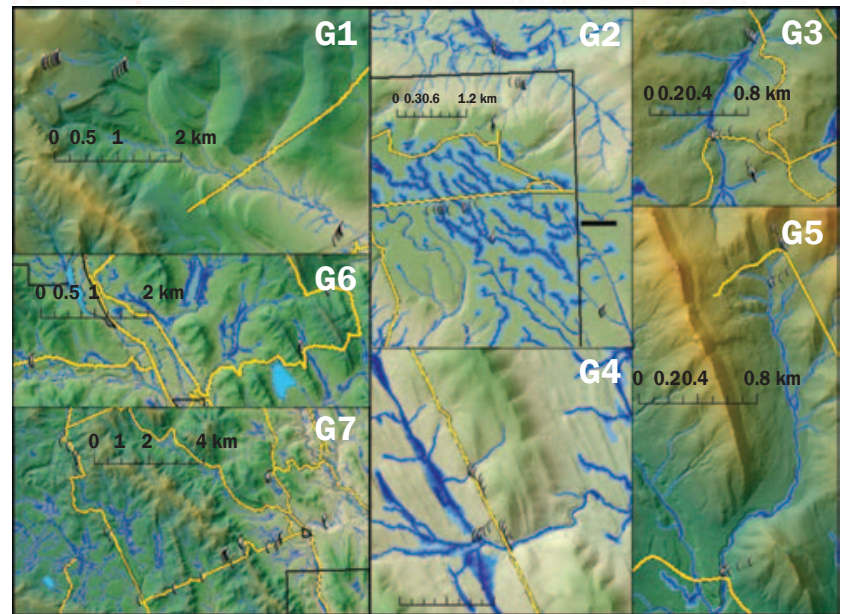

$(0.833 \mathrm{ft}) ; d=0.62 \mathrm{~m}(2.03 \mathrm{ft}) ; h=0.3 \mathrm{~m} \mathrm{(1}$ $\mathrm{ft}) ; p=34.4 \mathrm{kPa}$; and $n=10$ passes.

Cone Index, Rut Depth Mapping, and Trail Survey. CI and rut depth were mapped

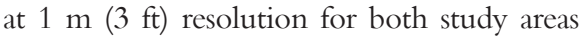
using (1) the DEM-derived rasters for $\log _{10}(\mathrm{DTW})$ and elevation, (2) the field-calibrated regression model for CI (i.e., equation 15 below) for the mapping purpose, and (3) equations 7 and 8 for the rut-depth calculations. The trail survey, done in August of 2010, involved a $40 \mathrm{~km}(25 \mathrm{mi})$ trail loop within the $605 \mathrm{~km}$ (376 mi) trail network of the GRFLUZ area (figure 1). Locations, length, and extent of trail damage was recorded by way of GPS tracking (Magellan CX; 1 m [3.2 $\mathrm{ft}]$ resolution, open conditions). The extent of trail damage was assessed in terms of 6 severity classes from none (class 0 ) to high (class 5 ), as described and illustrated in figure 4 . The resulting GIS tracks were overlaid on the DTW, CI, and ATV-specific rut depth maps and were analyzed in terms of $1 \mathrm{~m}$ trail segments by way of total length, mean, standard
Table 1

Overview of soil trafficability determining variables and units.

\begin{tabular}{|c|c|}
\hline Variable & Units \\
\hline $\mathrm{MCg}$ & $\%$ \\
\hline MCPS & $\%$ \\
\hline $\mathrm{Db}$ & $\mathrm{g} \mathrm{cm}^{-3}$ \\
\hline $\mathrm{Dp}$ & $\mathrm{g} \mathrm{cm}^{-3}$ \\
\hline PS & $\%$ \\
\hline$M C v_{\text {field }}$ & $\%$ \\
\hline $\mathrm{PS}_{\text {field }}$ & $\%$ \\
\hline $\mathrm{MCPS}_{\text {field }}$ & $\%$ \\
\hline Carbon content, C & $\%$ \\
\hline Sand & $\%$ \\
\hline Silt & $\%$ \\
\hline Clay & $\%$ \\
\hline $\mathrm{CF}$ & $\%$ \\
\hline $\mathrm{Cl}_{\text {depth }}$ & $\mathrm{cm}$ \\
\hline $\mathrm{Cl}_{\max }$ & $\mathrm{kg} \mathrm{m}^{-2}$ \\
\hline $\mathrm{LFH}_{\text {depth }}$ & $\mathrm{cm}$ \\
\hline Soil $_{\text {depth }}$ & $\mathrm{cm}$ \\
\hline DTW & $\mathrm{m}$ \\
\hline Elevation & $\mathrm{m}$ \\
\hline Slope & degree \\
\hline
\end{tabular}

Notes: $\mathrm{MCg}=$ gravimetric soil moisture. MCPS = water-filled fraction of pore space fraction (PS). $\mathrm{Db}=$ soil bulk density. $\mathrm{Dp}=$ soil particle density. $\mathrm{MCv}=$ volumetric soil moisture. $\mathrm{CF}=$ coarse fragment content. $\mathrm{Cl}=$ cone penetration. DTW = depth-to-water index. $\mathrm{LFH}_{\text {depth }}=$ depth of the forest floor consisting of the litter $(\mathrm{L})$, fermentation $(\mathrm{F})$, and/or humification $(\mathrm{H})$ layers.

deviation, minimum and maximum values, and frequency histograms by severity class.

\section{Results and Discussion}

Tables 1 and 2 present the units, mean, standard error, standard deviation, mode, and minimum and maximum values for each of the plot-based CI and CI determining variables including $\mathrm{CI}$, by study area. The correlation coefficients among these variables are compiled in table 3. Focusing on how CI relates to soil depth revealed the following: 1. Mean CI per soil core (up to $25 \mathrm{~cm}[9.8$

in]) increased linearly with increasing $\mathrm{CI}_{\text {max }}$ (figure 5).

2. CI tended to increase asymptotically with increasing soil depth towards CI (figure 5).

3. $\mathrm{CI}_{\max }$ decreased exponentially with increasing soil penetration depth (figure 5), i.e.,

$\mathrm{CI}=\mathrm{CI}_{\max }[1-\exp (-0.1$ soil depth $)]$ $r^{2}=0.53$, 


\section{Figure 4}

Severity classes of trail damage rating, with examples from the $40 \mathrm{~km}$ trail survey within the Ghost River Forest Land Use Zone (GRFLUZ) area.

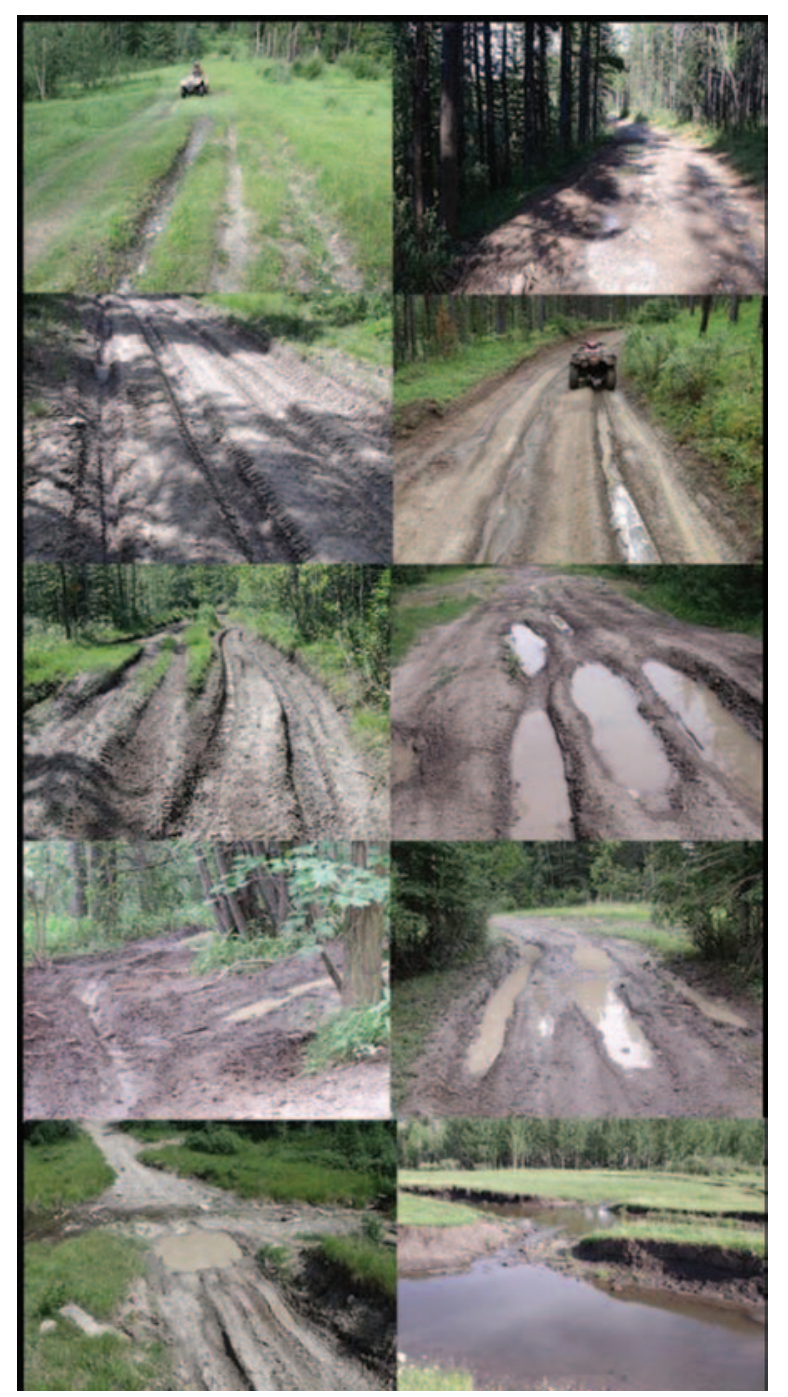

\section{Severity Class}

1. Root Scuffing; small sediment loss; occasional puddling; little potential for further damage.

2. Single to double track rutting and water retention with occasional braiding; potential for further damage.

3. Triple track rutting with substantial water retention and frequent braiding; potential for further damage.

4. Multiple track rutting beyond intended trail corridor with substantial water retention and frequent braiding; sediment loss to nearby waterways substantial; potential for further damage.

5. Multiple track rutting with water course alterations and destabilization of stream banks and shorelines; frequent braiding; potential for further or continual damage substantial.

with the more deeply penetrated soils having the generally the lower $\mathrm{CI}_{\max }$ values. The asymptotic approach of $\mathrm{CI}$ towards $\mathrm{CI}_{\text {max }}$ would in part be caused by the physical constraint of the field sampler to manually penetrate compacted soils at constant velocity above $\mathrm{CI} \approx 1.5 \mathrm{MPa}$ towards a maximum value of about $4 \mathrm{MPa}$. Using hydraulically driven penetrometers would have generated higher and nonasymptotic CI values, perhaps up to $\approx 8 \mathrm{MPa}$, as reported by Domsch et al. (2006) using $30^{\circ}$ cone tips $\left(100 \mathrm{~mm}^{2}\right.$ [0.16 $\left.\mathrm{in}^{2}\right]$ base) for a glacial drift area with sandy deposits overlying boulder clay. Blouin et al. (2011) reported CI values up to $10 \mathrm{MPa}$ using a $30^{\circ}$ cone with a $4 \mathrm{~mm}$ (0.16 in) base for wood-landing sites on a sandy-skeletal glaciofluvial substrate, while $\mathrm{CI}_{\max }$ remained less than $4 \mathrm{MPa}$ using a $30^{\circ}$ cone with a
$12.83 \mathrm{~mm}$ (0.51 in) base (American Society of Agricultural Engineers [ASAE] standard). A similar asymptotic CI trend with increasing soil depth towards $\mathrm{CI} \approx 3 \mathrm{MPa}$ (ASAE) for soils comprised of sandy surface deposits underlain by clay was reported by Sakai et al. (2008). Carter et al. (2007) reported linear CI increases with increasing soil depth up to CI $\approx 2.5 \mathrm{MPa}$ (ASAE) on a pine flat with loamy soils with slow to moderate permeability on unconsolidated sand, clays, and limestone.

Regressing the core-determined $\mathrm{Db}$ values against the equation 3 formulation for $\mathrm{Db}$ produced the following best-fitted result:

$\mathrm{Db}($ core $)=0.25( \pm 0.04)+1.00( \pm 0.04) \mathrm{Db}$ (equation 3); $r^{2}=0.62$; RMSE (root mean square error) $=0.18 \mathrm{~g} \mathrm{~cm}^{-3}$.
Regressing $\mathrm{Db}$ against core-determined texture, organic C, and CF values generated a similarly good regression model, i.e.,

$\mathrm{Db}($ core $)=1.25( \pm 0.02)+0.003( \pm 0.001)$

Clay $-0.029( \pm 0.002)$ OM $+0.36( \pm 0.04)$

$\mathrm{CF} ; r^{2}=0.65 ; \mathrm{RMSE}=0.12 \mathrm{~g} \mathrm{~cm}^{-3}$.

Regressing MCPS $_{\text {field }}$ against $\log _{10}(\mathrm{DTW})$ and study area code (GRFLUZ $=0$, EMEND = 1) produced the following best-fitted result (figure 6):

$\mathrm{MCPS}_{\text {field }}=62.3( \pm 1.1) \quad-13.7( \pm 0.9)$ $\log _{10}($ DTW $)-28.9( \pm 1.5)$ Study area; $r^{2}=$ $0.59 ; \mathrm{RMSE}=16.4 \%$,

thereby indicating that $\log _{10}$ (DTW) is a good predictor for $\mathrm{MCPS}_{\text {field }}$ and the soils within the 
Table 2

Descriptive statistics summary for the soil trafficability determining variables within the Ghost River Forest Land Use Zone (GRFLUZ) and Ecosystem Management Emulating Natural Disturbance (EMEND) study areas.

\begin{tabular}{|c|c|c|c|c|c|c|c|c|c|c|c|c|}
\hline \multirow[b]{2}{*}{ Variable } & \multicolumn{6}{|c|}{ GRFLUZ } & \multicolumn{6}{|l|}{ EMEND } \\
\hline & Mean & $\begin{array}{l}\text { Standard } \\
\text { error }\end{array}$ & Mode & $\begin{array}{l}\text { Standard } \\
\text { deviation }\end{array}$ & $\begin{array}{l}\text { Mini- } \\
\text { mum }\end{array}$ & $\begin{array}{l}\text { Maxi- } \\
\text { mum }\end{array}$ & Mean & $\begin{array}{l}\text { Standard } \\
\text { error }\end{array}$ & Mode & $\begin{array}{l}\text { Standard } \\
\text { deviation }\end{array}$ & $\begin{array}{l}\text { Mini- } \\
\text { mum }\end{array}$ & $\begin{array}{l}\text { Maxi- } \\
\text { mum }\end{array}$ \\
\hline $\mathrm{MCg}$ & 108 & 11.1 & 520 & 175 & 14.3 & 522 & 18 & 0.5 & 14.5 & 8.6 & 1.4 & 60.3 \\
\hline MCPS & 72 & 1.1 & 100 & 17.6 & 25.9 & 100 & 51.6 & 1.2 & 100 & 19.6 & 4.8 & 100 \\
\hline $\mathrm{Db}$ & 1 & 0.02 & 1 & 0.3 & 0.16 & 1.5 & 1.35 & 0 & 1.4 & 0.2 & 0.8 & 1.9 \\
\hline Dp & 2 & 0.03 & 2.5 & 0.5 & 1 & 2.6 & 2.47 & 0 & 2.5 & 0.1 & 1.8 & 2.6 \\
\hline PS & 51 & 1.2 & 0 & 19 & 0 & 87.7 & 45.5 & 0.4 & 44.3 & 6.5 & 26.5 & 62.8 \\
\hline$M C v_{\text {field }}$ & 44 & 1.7 & 100 & 26.7 & 9.8 & 100 & 22.3 & 0.9 & 15.4 & 14.1 & 3.9 & 63 \\
\hline $\mathrm{PS}_{\text {field }}$ & 65 & 1 & 100 & 14 & 50 & 100 & 60 & 0 & 60 & 10 & 50 & 80 \\
\hline MCPS $_{\text {field }}$ & 63 & 1.4 & 100 & 21.9 & 18.1 & 100 & 36.6 & 1.4 & 100 & 21.8 & 6.8 & 100 \\
\hline C & 11 & 1.3 & 58.1 & 19.8 & 0.7 & 58.1 & 3.2 & 0.2 & 1.8 & 2.6 & 0.7 & 26.9 \\
\hline Sand & 37 & 1.1 & 0 & 17.9 & 0 & 84.1 & 28.7 & 0.5 & 25.6 & 7.9 & 8.1 & 55 \\
\hline Silt & 33 & 1 & 0 & 15.3 & 0 & 63.9 & 33.8 & 0.4 & 31 & 5.9 & 15.2 & 51.6 \\
\hline Clay & 16 & 0.6 & 0 & 8.8 & 0 & 38 & 37.5 & 0.5 & 32.8 & 7.3 & 14.6 & 63.5 \\
\hline CF & 10 & 1 & 0 & 12 & 0 & 56 & 40 & 0 & 40 & 20 & 0 & 70 \\
\hline $\mathrm{Cl}_{\max }$ & 10 & 0.4 & 0 & 6.9 & 0 & 31 & 17.8 & 0.6 & 2 & 9.5 & 2 & 35 \\
\hline $\mathrm{LFH}_{\text {depth }}$ & 10 & 1 & 0 & 16.3 & 0 & 100 & 12.7 & 0.6 & 9 & 9.6 & 3 & 81 \\
\hline Soil ${ }_{\text {depth }}$ & 21 & 0.9 & 0 & 14.1 & 0 & 100 & 17.2 & 0.3 & 17.5 & 4 & 0 & 23.8 \\
\hline DTW & 7 & 0.8 & 0 & 12.3 & 0 & 73.1 & 1.9 & 0.2 & 0.2 & 2.5 & 0 & 16.2 \\
\hline Elevation & 1,532 & 6.5 & 1,569 & 102 & 1,360 & 1,758 & 747 & 2.6 & 713 & 42 & 684 & 822 \\
\hline Slope & 9 & 0.4 & 3 & 6.7 & 0 & 32.3 & 3.9 & 0.3 & 2 & 4.5 & 0.1 & 25.7 \\
\hline
\end{tabular}

Notes: MCg = gravimetric soil moisture. MCPS = water-filled fraction of pore space fraction (PS). Db = soil bulk density. Dp = soil particle density. MCv

= volumetric soil moisture. $\mathrm{CF}=$ coarse fragment content. $\mathrm{Cl}=$ cone penetration. $\mathrm{DTW}=$ depth-to-water index. $\mathrm{C}=$ carbon content.

Table 3

Correlation coefficients pertaining to the soil trafficability determining variables within the Ghost River Forest Land Use Zone (GRFLUZ) and Ecosystem Management Emulating Natural Disturbance (EMEND) study areas.

\begin{tabular}{|c|c|c|c|c|c|c|c|c|c|c|c|c|c|c|}
\hline Variable & $\mathrm{MCg}$ & $\mathrm{Db}$ & $\mathbf{M C v}_{\text {field }}$ & C & Sand & Clay & CF & $\mathbf{C l}_{\max }$ & $\mathbf{L F H}_{\text {depth }}$ & $\begin{array}{l}\log _{10} \\
\text { DTW }\end{array}$ & Elevation & Slope & $\begin{array}{l}\log _{10} \\
\text { Soil } \\
\text { depth }\end{array}$ & $\begin{array}{l}\log _{10} \\
\mathrm{Cl}_{\text {depth }}\end{array}$ \\
\hline $\mathrm{MCg}$ & 1 & & & & & & & & & & & & & \\
\hline $\mathrm{Db}$ & -0.86 & 1 & & & & & & & & & & & & \\
\hline$M C v_{\text {field }}$ & 0.83 & -0.73 & 1 & & & & & & & & & & & \\
\hline C & 0.99 & -0.89 & 0.84 & 1 & & & & & & & & & & \\
\hline Sand & -0.67 & 0.48 & -0.56 & -0.6 & 1 & & & & & & & & & \\
\hline $\mathrm{CF}$ & -0.52 & 0.52 & -0.4 & -0.49 & 0.39 & 0.50 & 1 & & & & & & & \\
\hline $\mathrm{Cl}_{\max }$ & -0.43 & 0.48 & -0.75 & -0.46 & 0.32 & 0.18 & 0.22 & 1 & & & & & & \\
\hline $\mathrm{LFH}_{\text {depth }}$ & 0.79 & -0.65 & 0.79 & 0.78 & -0.54 & -0.60 & -0.43 & -0.49 & 1 & & & & & \\
\hline $\log _{10}$ DTW & -0.27 & 0.25 & -0.44 & -0.27 & 0.28 & 0.14 & 0.31 & 0.51 & -0.18 & 1 & & & & \\
\hline Elevation & 0.97 & -0.84 & 0.8 & 0.96 & -0.62 & -0.73 & -0.43 & -0.41 & 0.76 & -0.23 & 1 & & & \\
\hline
\end{tabular}




\section{Figure 5}

(a) Relating mid-core cone index $(\mathrm{Cl})$ at $15 \mathrm{~cm}$ depth $\left(y=\mathrm{Cl}_{\text {core }}\right)$ to $\mathrm{Cl}$ at maximum penetration depth $\left(\mathrm{x}=\mathrm{Cl}_{\max }\right.$ ), with best-fitted model. (b) Scatterplot and best-fitted model showing $\mathrm{Cl} / \mathrm{Cl}_{\max }$ $\left(y\right.$-axis) against soil depth ( $x$-axis). (c) Scatterplot of $\mathrm{Cl}_{\max }$ ( $y$-axis) versus maximum soil penetration depth ( $x$-axis). The equations and $r^{2}$ values refer to the best fitted models.

(a)

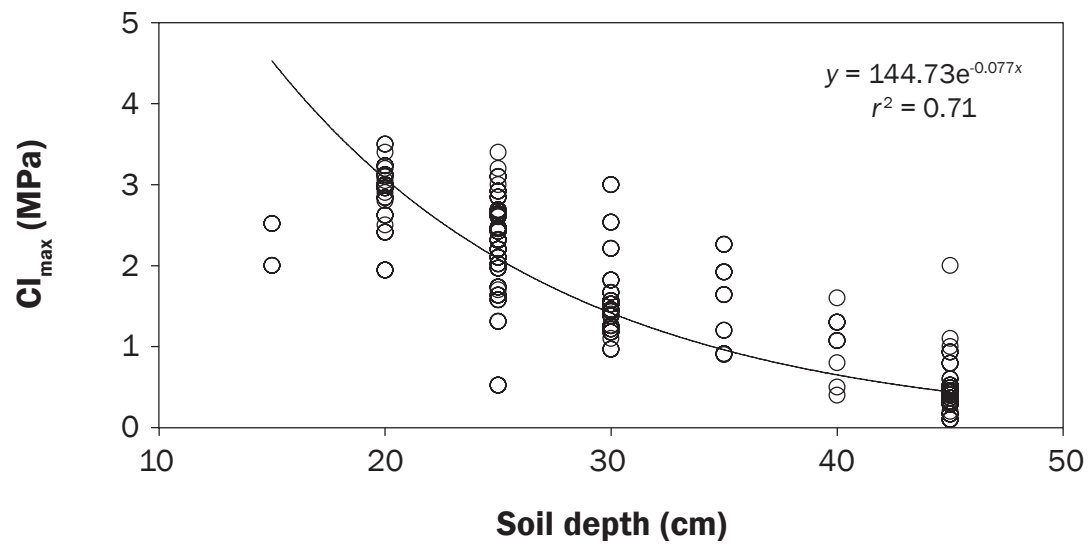

(b)

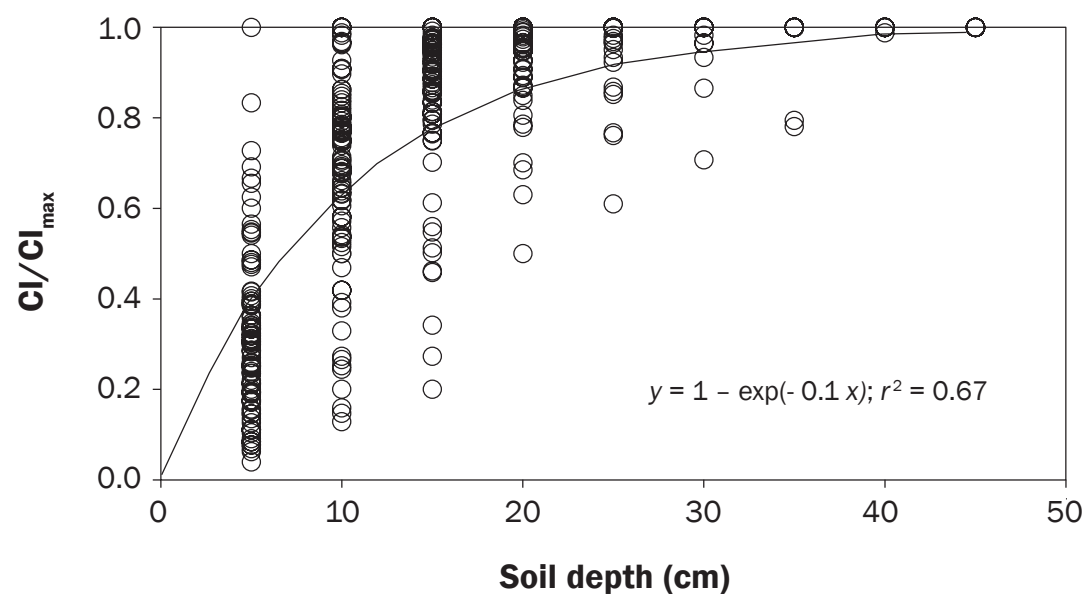

(c)

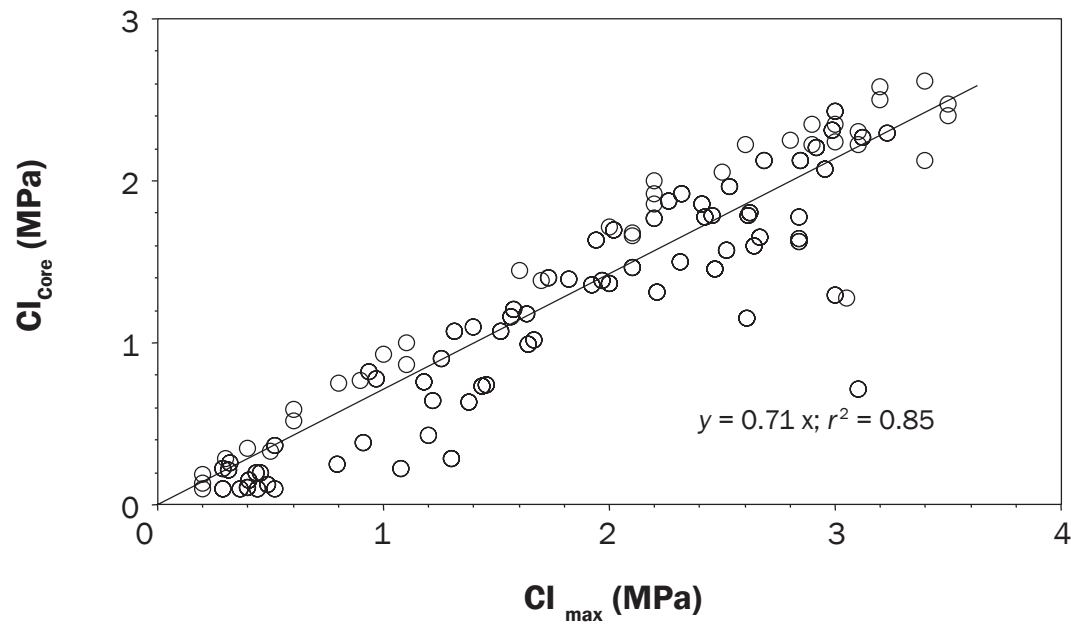

sampling plots were generally moister for the GRFLUZ than the EMEND area due to wetter weather conditions at the time of sampling.

Regressing the field-determined $\mathrm{CI}_{\text {max }}$ values against CI (equation 2) led to the following result for both study areas (figure 6):

$\log _{10} \mathrm{CI}_{\max }=-0.251( \pm 0.018)+0.88( \pm 0.04)$ $\log _{10} \mathrm{CI}_{\text {max }}^{\max }($ equation 2$) ; r^{2}=0.48$; RMSE $=$ 0.22 ,

with each plot-based CI value estimated via equation 2 as follows:

1. using Sand (\%) and OM (\%) as determined from the soil core samples,

2. using the Theta Moisture Probe (TDR) determined $\mathrm{MCv}_{\text {field }}$ soil moisture measurements, and

3. inferring the required equation 2 entry values for $\mathrm{Db}_{\text {field }}, \mathrm{PS}_{\text {field }}$, and MCPS from these determinations using equations 3 to 6 .

The best-fitted scatter plot in figure 6 shows that the field-determined $\mathrm{CI}_{\text {max }}$ values conform to CI (equation 2) quite well, but with an under-prediction bias, likely due to two reasons: (1) the manually produced $\mathrm{CI}_{\text {max }}$ data level off as soil resistance to penetration increases with increasing soil depth (figure 5 ) and (2) equation 2 summarizes CI trends across several studies with interstudy biases removed (Vega-Nieva et al. 2009). Such biases refer to study-to-study differences in cone angle and size, penetration velocity, extent of soil cementation, and other variations in site and study conditions.

Regressing $\mathrm{CI}_{\max }$ directly against the plot and core-based Sand, PS, and MCPS ${ }_{\text {field }}$ fractions produced the following best-fitted result:

$\log _{10} \mathrm{CI}_{\max }=1.09( \pm 0.07)-1.03( \pm 0.11) \mathrm{PS}-$ $0.90( \pm 0.0003) \mathrm{MCPS}_{\text {field }} ; r^{2}=0.69$; RMSE $=19 \%$.

Note that other variables such as Sand and/or Clay, OM, and coarse fragment content did not enter the equation as $\mathrm{CI}_{\max }{ }^{-}$ determining regression variables. However, soil texture and OM do affect CI and therefore $\mathrm{CI}$ via $\mathrm{Db}, \mathrm{Dp}, \mathrm{PS}$, and MCPS according to equations 5 to 8 (Balland et al. 2008). In comparison, the best-fitted $r^{2}$ value for equation $14\left(r^{2}=0.69\right)$ is

1. somewhat higher than the corresponding value for equation 13 , due to the direct use of the plot and core-determined PS and MCPS $_{\text {field }}$ values, and 


\section{Figure 6}

(a) Best-fitted scatter plots generated by regressing the field-measured water-filled pore space (MCPS) values (TDR) against plot-specific $\log _{10}$ (depth-to-water [DTW] index) and elevation (equation 12). (b) Scatterplot of the field-determined $\log _{10}$ (cone index at maximum penetration $\left[\mathrm{Cl}_{\text {max }}\right]$ ) data generated for the Ecosystem Management Emulating Natural Disturbance (EMEND) and Ghost River Forest Land Use Zone (GRFLUZ) areas versus the corresponding $\log _{10} \mathrm{Cl}$ values predicted from equation 2. (c) Best-fitted scatter plot obtained by regressing $\mathrm{Cl}$ at $10 \mathrm{~cm}$ soil depth against field-determined MCPS $_{\text {field }}$ and plot-specific $\log _{10}$ DTW values (equation 16).

(a)

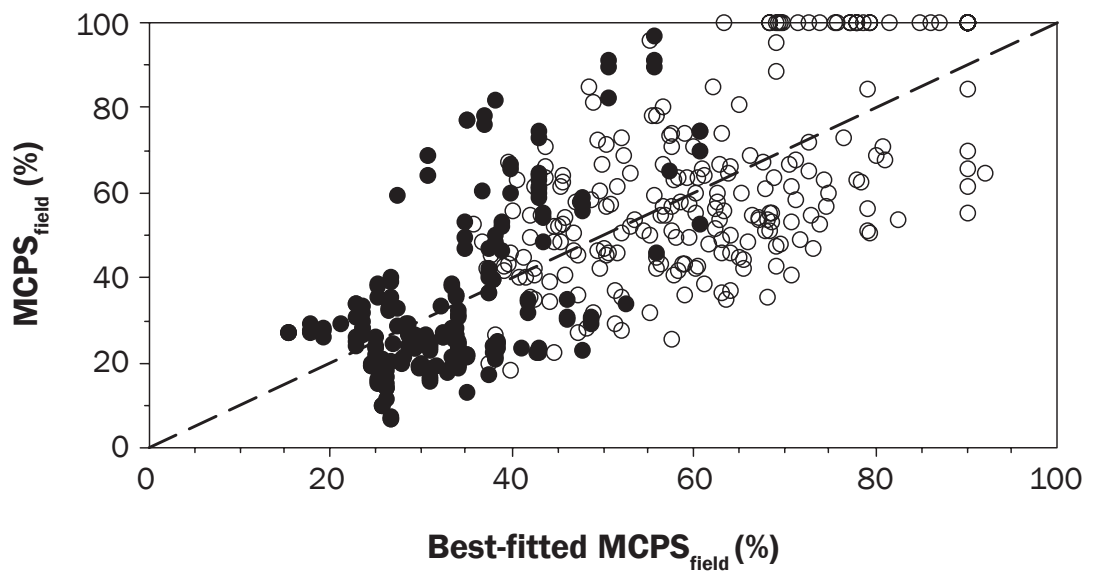

(b)

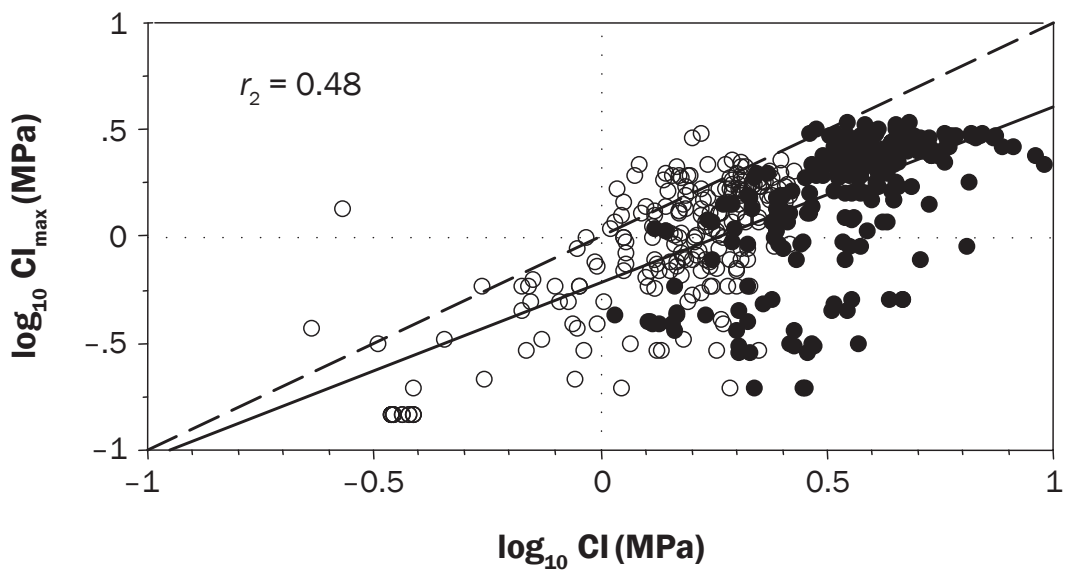

(c)

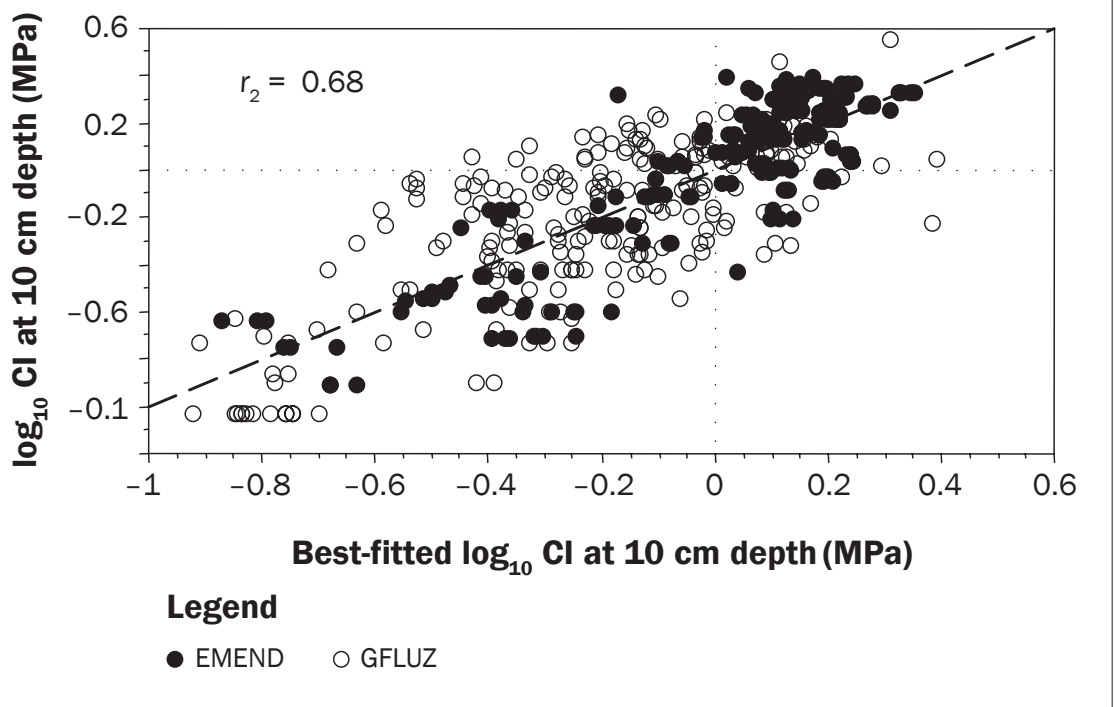

2. somewhat lower than the corresponding values for equations 1 and $2\left(r^{2}=0.77\right.$ and 0.85 , respectively), mainly due to the more limited range of the manually derived CI values, i.e., $\mathrm{CI} \leq 3$ (equations 13 and 14 ) versus $\mathrm{CI} \leq 7 \mathrm{MPa}$ (equation 2 ).

Using $\mathrm{CI}_{\max }$ via equation 9 to determine $\mathrm{CI}$ at $10 \mathrm{~cm}$ (4 in) soil depth, and regressing the result so obtained against each plot-specific but DEM-derived $\log _{10}(\mathrm{DTW})$ and elevation value produced the following result:

$\log _{10} \mathrm{CI}_{10 \mathrm{cmdepth}}=0.27( \pm 0.04)+0.283( \pm 0.011)$ $\log _{10}$ DTW - 0.00041( \pm 0.00003$)$ Elevation; $r^{2}=0.47$; $\mathrm{RMSE}=0.27$.

Using the field-determined $\mathrm{MCPS}_{\text {field }}$ values instead of elevation improved the correspondence between the mapped and the plot-specific CI determinations as follows (figure 6):

$\log _{10} \mathrm{CI}_{10 \mathrm{cmdepth}}=0.36( \pm 0.02)+0.133( \pm 0.012)$ $\log _{10}$ DTW - 1.05( \pm 0.004$) \mathrm{MCPS}_{\text {field }} ; r^{2}=$ $0.68 ; \mathrm{RMSE}=0.21$.

Using equation 15 produced the GRFLUZ and EMEND CI maps in figure 7, with transect-focused close ups for a visual comparison between the plot-determined and the map-generated CI values. While there is general conformance between plotdetermined and the DEM-generated CI values via equation 15 , differences also occur. These differences likely stem from as yet unmapped details regarding local variations pertaining to DTW, soil density, moisture, texture, and OM and coarse fragment content. For example, some of the upper reaches of the DEM-derived flow channels with 1 ha $(2.5 \mathrm{ac})$ flow initiation areas become dry during dry summer conditions, and therefore produce much higher CI values than mapped via equation 12 . When these channels dry, adjacent and upslope areas are already dry and therefore increase their resistance to cone penetration. This is illustrated in figure 7 for the fairly flat EMEND transect locations E1 and E2, where the mapped CI values remain low relative to flow channels with 1 ha flow initiation (i.e., dots located within the channel areas shaded dark red). The late summer plot determinations for CI, however, exceed the mapped values by one to two orders of magnitude, unless they fall close to the mapped flow channels with 4 ha $(10 \mathrm{ac})$ flow initiation (blue lines). Note that 


\section{Figure 7}

Overlay of the plot-determined and mapped cone index $(\mathrm{Cl})$ at $10 \mathrm{~cm}$ depth (equation 16 ) at select transect locations within the (a) Ghost River Forest Land Use Zone (GRFLUZ) and (b) Ecosystem Management Emulating Natural Disturbance (EMEND) area. The GRFLUZ and EMEND CI maps were generated using the digital elevation-derived flow channel networks with 4 and 1 ha flow initiation, respectively. The blue lines for the EMEND area on the right refer to the streams with 4 ha flow initiation. The plot determinations refer to mid (GRFLUZ) to late (EMEND) summer conditions.

(a)

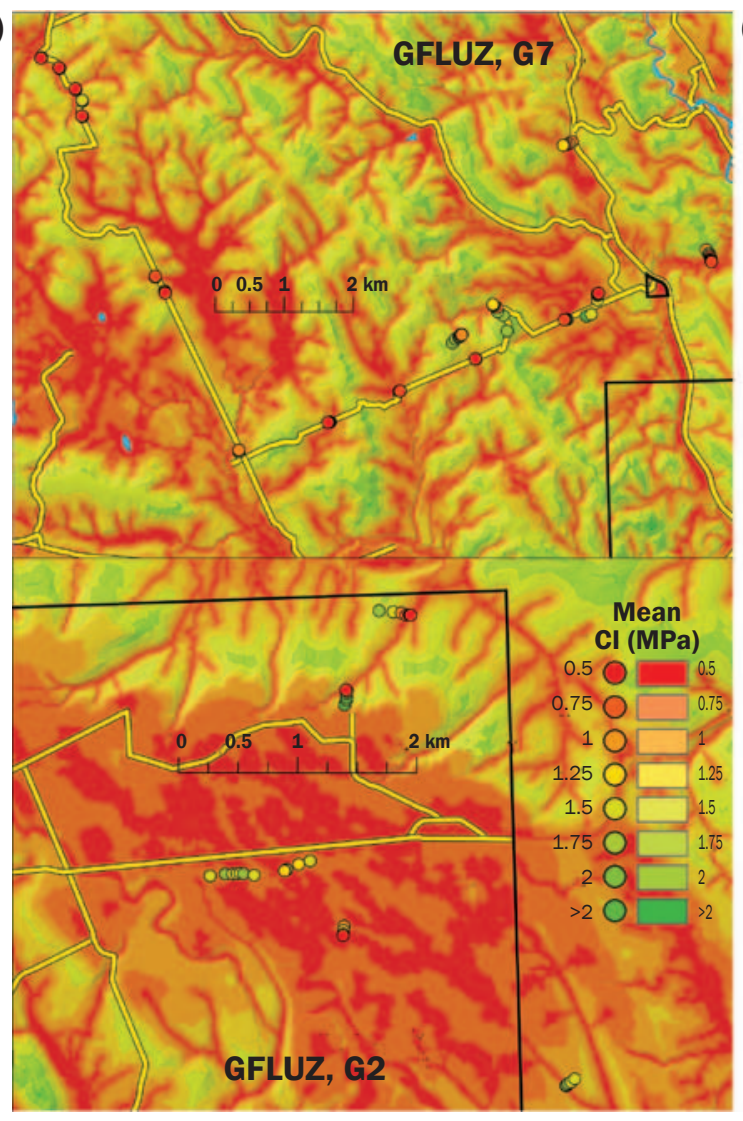

(b)

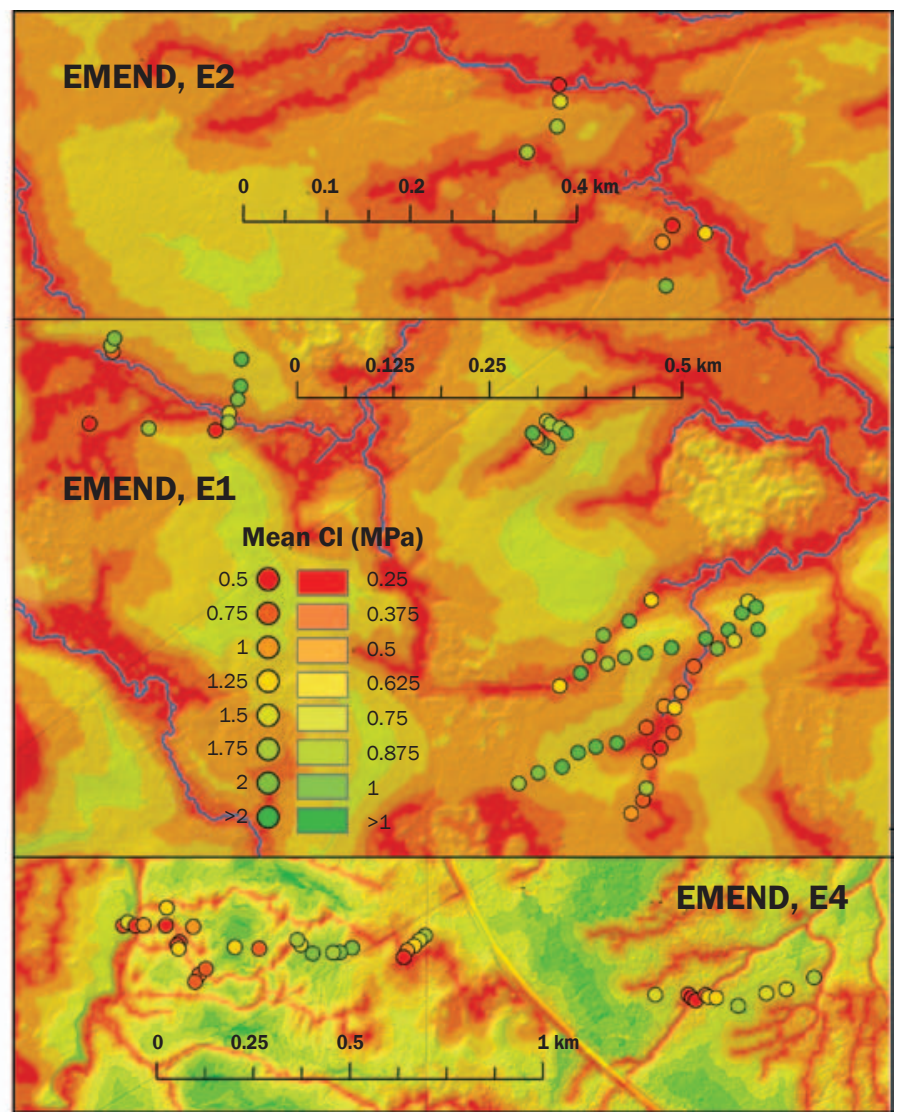

these differences are less accentuated in hilly areas as shown by the E4 transect location at EMEND, where the soils along the slopes drain and dry while the stream channels and adjacent soils within the valleys below continue to receive seeps and base flow.

Higher or lower CI values than mapped may also occur on account of variations in soil and substrate permeability, with coarse-textured soils generally drier than fine-textured soils. This is the case for the floodplain area within the GRFLUZ G2 location in figure 7 and where the extent of season- and weather-dependent water supply varies within each 4 or 1 ha (10 or 2.5 ac) flow-accumulation area for stream initiation. The weather-dependent component would in part be influenced by the extent of vegetation cover and related evapotranspirational water losses and upslope soil disturbances including soil compaction which affects runoff initiation following precipitation events and lower soil percolation rates thereafter (Rab et al. 2005; Foltz 2006).
Some of the vegetation-related, season-related, and weather-related complications can, at least in part, be accommodated by calibrating equation 16 with hydrologically derived soil moisture levels from ridge tops to depressions, as outlined by Vega-Nieva et al. (2009).

The survey results pertaining to the extent of rutting damage along the $40 \mathrm{~km}$ (25 mi) trail segments within the GRFLUZ area are as follows:

1. Figure 8 shows an overlay of the field-determined CI values at $10 \mathrm{~cm}$ [3.9 in] soil depth over the corresponding rut map generated via equations 7,8 , and 15 .

2. Table 4 shows the total length of damaged trail by damage severity class, and also lists the mean, standard error, and minimum and maximum of DTW, log${ }_{10}$ DTW, CI, $\log _{10}$ CI, NCI, and NCI-projected rut depth for each $1 \mathrm{~m}(3 \mathrm{ft})$ trail segment by damage severity class.

3. Figure 9 shows histograms for a. the number of $1 \mathrm{~m}(3 \mathrm{ft})$ trail segments per damage severity class as they fall into each of the $5 \mathrm{~m}(16 \mathrm{ft})$ DTW classes from 0 to $120 \mathrm{~m}$ (0 to $394 \mathrm{ft}$ ) (left), and

b. the relative frequency of damaged trail segments per severity class as they fall into the CI-projected rut-depth classes up to $45 \mathrm{~cm}$ (17.7 in).

The vertical line (figure $9 \mathrm{~b}$ ) refers to the approximate clearance of the recreational vehicle from the ground. These results conform to general expectations and experiences: Most of the severe trail damage occurred in wet areas as demonstrated by the increasing occurrence of the higher severity classes within the lower DTW classes and where the rut depth was modeled and mapped to be high (figure 8 ). In contrast, trail damage for severity class 1 was least DTW dependent (figure 9 left). Trail damage attributed to this class would be due to gradual wear and tear along the better drained trail segments, where 


\section{Figure 8}

(a) Trail damage severity classes along trail segments (40 km, figure 1) within the Ghost River Forest Land Use Zone (GRFLUZ) study area, overlaid on the equations 7 and 8 generated rutdepth map (all-terrain recreational vehicle [ATV], 10 passes).(b) Close-up of the northern portion of the surveyed trail.

(a)

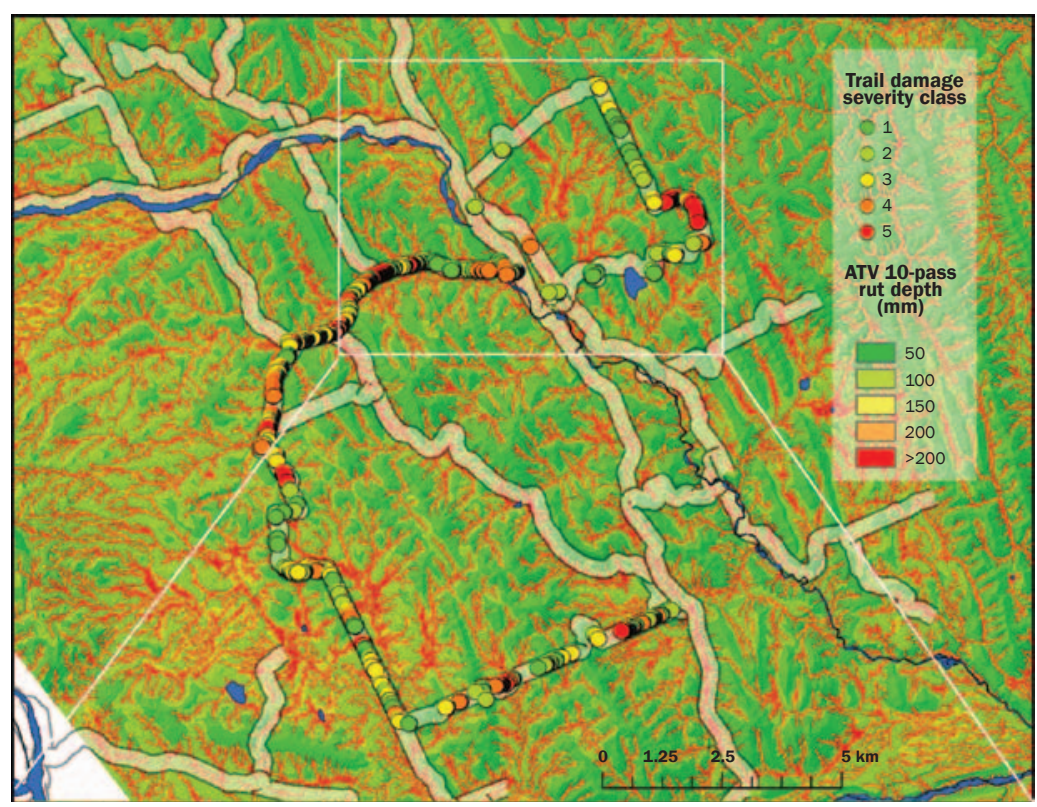

(b)

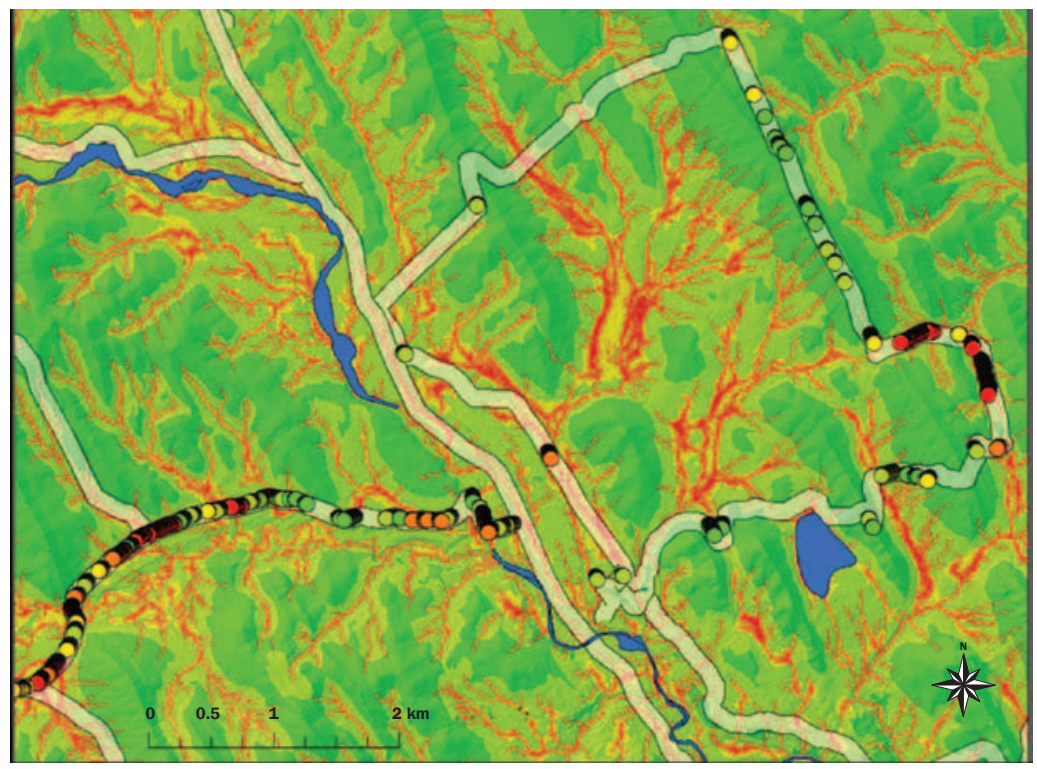

the main damage would be restricted to wet weather-induced puddling and runoff.

Plotting the percentage distribution of the trail severity classes against modelled rut depth (figure 10) revealed that the locations of no significant damage (severity 0 ) are consistent with where the mapped rut depth for 10 ATV passes would be less than $2.5 \mathrm{~cm}(1$ in) deep. Damage classes 1 and 2 dominate where the 10 ATV passes are mapped to of vehicle passes;

2. reduced subsoil drainage across tracks, thereby softening of the ground upslope adjacent to the tracks;

3. mud-producing water retention within the deepening ruts;

4. trail braiding;

5. washouts along trail-crossing seepage flows;

6. formation of gullies; and

7. subsequent sediment transfers and general down-slope flow channel alterations (Bauer 2003; Bruehler and Sondergaard 2004;

Marion and Olive 2006; Riedel 2006).

Altogether, trail damage was most severe where DTW was less than $2 \mathrm{~m}(7 \mathrm{ft})$, where the mapped 10-pass ATV rut depths were greater than $0.5 \mathrm{~m}(1.6 \mathrm{ft})$, and where the soil would generally be moist to wet. Damage was less severe on more elevated ground locations further away from the stream channels where DTW was greater than $2.5 \mathrm{~m}(8.2 \mathrm{ft})$ and less than $10 \mathrm{~m}(32.8 \mathrm{ft})$, thereby producing generally intermediate $\mathrm{CI}$ values and rut depths. Damage was least severe to generally absent on well-drained ground where DTW was greater than $10 \mathrm{~m}$, and 10-pass ATV rut depth was less than $2.5 \mathrm{~cm}$ (1 in). Remapping the rutting potential with DTW referenced to the local flow channel network with 1 ha $(2.5 \mathrm{ac})$ flow initiation captured most of the rut locations that were not captured with the 4 ha $(10 \mathrm{ac})$ flow initiation channels (figure 8). However, expanding the flow channel network towards the ridges to simulate wetter conditions lowered the mapped DTW, $\mathrm{CI}$, and rut depth values everywhere.

While the above estimates are specific to a particular ATV type and load, equations 7 and 8 permit estimating potential rutting depth by varying machine type and load. For example, a $4 \times 4$ truck ( $W=$ vehicle weight + load $=16.7 \mathrm{kN}, b=0.210 \mathrm{~m}(0.689 \mathrm{ft}), d$ $=0.782 \mathrm{~m}(2.566 \mathrm{ft}), h=0.267 \mathrm{~m}(0.876 \mathrm{ft})$, $p=34.4 \mathrm{kPa}, n=10$ passes) would generate ruts about 5.2 times deeper than the above ATV ruts for the same soil conditions.

In reference to the Waterways Experiment Station method and related elaborations (Rab et al 2005; Priddy and Willoughby 2006), the above CI and rut-depth formulation presents a practical albeit simplified approach to model and map soil resistance to penetration and related mechanical disturbances across landscapes: rutting due to tire spinning and subsequent soil displacement is not considered. The role of DTW as dominant indicator of soil pene- 


\section{Table 4}

All-terrain recreational vehicle (ATV) trail survey summary: length, cartographic depth-to-water (DTW and $\log _{10}$ [DTW]), soil penetration cone index $\left(\mathrm{Cl}\right.$ and $\left.\log _{10}[\mathrm{Cl}]\right)$, vehicle specific normalized $\mathrm{Cl}$ index $(\mathrm{NCl})$, and 10-pass ATV rut depth, along a $40 \mathrm{~km}$ track, by trail damage severity class.

\begin{tabular}{|c|c|c|c|c|c|c|}
\hline \multirow[b]{2}{*}{ Variable } & & \multicolumn{5}{|c|}{ Trail damage severity class } \\
\hline & & 1 & 2 & 3 & 4 & 5 \\
\hline Length $(m)$ & Sum & 1,671 & 2,422 & 3,311 & 2,388 & 2,648 \\
\hline \multirow[t]{4}{*}{ DTW (m) } & Mean & 19.3 & 10.4 & 7.6 & 4.4 & 1.2 \\
\hline & Std. dev. & 25.7 & 17.9 & 8.8 & 7.7 & 1.7 \\
\hline & Minimum & 0.1 & 0.01 & 0.01 & 0.002 & 0.003 \\
\hline & Maximum & 97.1 & 104.3 & 31.2 & 27.0 & 8.5 \\
\hline \multirow[t]{4}{*}{$\log _{10}($ DTW [m] $)$} & Mean & 0.809 & 0.591 & 0.36 & -0.117 & -0.229 \\
\hline & Std. dev. & 0.747 & 0.634 & 0.85 & 0.884 & 0.578 \\
\hline & Minimum & -1.15 & -2.00 & -2.29 & -2.61 & -2.50 \\
\hline & Maximum & 1.99 & 2.02 & 1.49 & 1.43 & 0.93 \\
\hline \multirow[t]{4}{*}{$\mathrm{Cl}(\mathrm{MPa})$} & Mean & 0.936 & 0.812 & 0.724 & 0.556 & 0.473 \\
\hline & Std. dev. & 0.378 & 0.307 & 0.331 & 0.313 & 0.165 \\
\hline & Minimum & 0.230 & 0.171 & 0.114 & 0.098 & 0.099 \\
\hline & Maximum & 1.66 & 1.71 & 1.34 & 1.24 & 0.92 \\
\hline \multirow[t]{4}{*}{$\log _{10}(\mathrm{Cl}[\mathrm{MPa}])$} & Mean & -0.068 & -0.121 & -0.195 & -0.32 & -0.353 \\
\hline & Std. dev. & 0.194 & 0.167 & 0.232 & 0.238 & 0.158 \\
\hline & Minimum & -0.639 & -0.766 & -0.945 & -1.007 & -1.004 \\
\hline & Maximum & 0.219 & 0.232 & 0.126 & 0.093 & -0.038 \\
\hline \multirow[t]{4}{*}{$\mathrm{NCl}$} & Mean & 87.1 & 75.6 & 67.4 & 51.7 & 44.0 \\
\hline & Std. dev. & 35.2 & 28.6 & 30.8 & 29.1 & 15.4 \\
\hline & Minimum & 21.4 & 16.0 & 10.6 & 9.2 & 9.2 \\
\hline & Maximum & 154.0 & 158.9 & 124.3 & 115.4 & 85.2 \\
\hline \multirow[t]{4}{*}{ ATV rut depth $(\mathrm{m})$} & Mean & 0.1 & 0.11 & 0.141 & 0.186 & 0.186 \\
\hline & Std. dev. & 0.05 & 0.048 & 0.089 & 0.099 & 0.076 \\
\hline & Minimum & 0.047 & 0.045 & 0.058 & 0.062 & 0.084 \\
\hline & Maximum & 0.335 & 0.449 & 0.678 & 0.783 & 0.777 \\
\hline
\end{tabular}

trability is perhaps not surprising because DTW indexes the least-cost depth from the soil surface to the water table below the soil surface when referenced by the nearest cartographically captured open-water locations. Hence, DTW not only allows for approximate mapping of soil moisture regimes and drainage but also for mapping other soil properties such as texture, density, and OM content (Murphy et al. 2009, 2011). For practical consideration, coarse fragments should also be part of the CI and rut depth calculation. These authors also also showed that the above soil properties conform more closely to the mapped DTW index than the widely used DEM-derived topographic wetness index (i.e., TWI = $\ln ([$ low accumulation $\div$ slope $])$. For that purpose, Vega-Nieva et al. (2009) suggested using $1 \div(1-\mathrm{CF})^{2}$ and $(1-\mathrm{CF})^{2}$ as CI and rut depth multipliers, respectively. Normally, small gravel-like particles embedded within the fine earth do not strongly affect CI as the penetrometer pushes these fragments to the side. With increasing CF size, however, CI readings become erratic and are limited to the distance above the solidly embedded fragments. In general, CI would increase with increasing CF, and, hence, thereby projecting decreasing rutting depths.

For context of the monitoring of machine-induced soil disturbances and compaction (Miller et al. 2010), one can use the CI-based rut-depth projections to estimate the extent of soil compaction and subsequent moisture content within the rut-impacted soil as follows (Vega-Nieva et al. 2009):

$\mathrm{PS}_{\mathrm{n}}=1-\mathrm{Db} \div \mathrm{Dp}-\mathrm{Z}_{\mathrm{n}} \div \mathrm{h}_{\text {soil }}$

and

$\operatorname{MCPS}_{\mathrm{n}}=\min \left(1, \operatorname{MCPS}, \mathrm{PS} \div \mathrm{PS}_{\mathrm{n}}\right)$,

where Db, PS, MCPS, and $h_{\text {soil }}$ refer, respectively, to prerut soil bulk density, pore space, water-filled portion of the pore space, and depth of compactable soil. In turn, the esti- mates for $\mathrm{PS}_{\mathrm{n}}$ and MCPS $\mathrm{n}$ can then be used to determine the resulting changes in $\mathrm{CI}, \mathrm{Db}$, PS, and MCPS within the ruts.

\section{Summary and Conclusions}

The results of this study suggest that the equation 2 formulation for $\mathrm{CI}$ or its reformulation via equation 15 quantify the functional dependency of CI on soil texture, density, and moisture content quite well at $r^{2} \approx 70 \%$. This result should be useful for mapping CI and potential rut depth thematically, using soil texture, density, and moisture content as CI and machine-specific rut-depth predictors by soil type. Mapping CI and rut depths in topographic detail, however, requires relating the CI predictor variables to topographic position. As shown, this can be done by relating the CI determining predictor variables (i.e., soil texture, density, and moisture content) to the DEM-derived elevation, slope, and $\log _{10}$ DTW variables, with $r^{2}$ values of about $50 \%$. This can be further improved to at least $66 \%$ by using field-measured soil moisture values. Further improvements would require soil moisture forecasts across the landscape by season and weather. However, even without this detail, checking the trail soil damage within the GRFLUZ area produced a general conformance between the field-rated soil disturbance severity classes and the corresponding DEM-derived DTW and rut-depth projections. The maps so produced should therefore be useful in terms of sizing potential trouble spots along existing trails and as a means to relocate existing trail segment along alternative less water-challenged routes. Altogether, we suggest that the DTW-based modeling and mapping protocol for soil penetrability and rutting depth provides a planning tool for directing or relocating trails away from areas that would otherwise incur considerable traffic-induced damage to soils, vegetation, and waterways.

\section{Acknowledgements}

We are grateful to Alberta's Sustainable Resource Development Department (Forestry and Lands Division) for financial and in-kind support. We are thankful for the interest and data support from the Ghost-Waiparous Stewardship Committee of the Ghost River Forest Land Use Zone

area, and from Ecosystem Management Emulating Natural Disturbance research partners. This soil trafficability research is also supported by a National Sciences and Engineering Research Council of Canada-supported Industry-University Cooperative Research and Development Partnership Grant. 


\section{Figure 9}

Histograms for the Ghost River Forest Land Use Zone (GRFLUZ) trail damage survey. (a) $1 \mathrm{~m}$ trail segment counts per damage severity class versus depth-to-water index (DTW), referenced to the digital elevation model-derived flow channel network with 4 ha flow accumulation at flow initiation. (b) Relative frequency of trail damage versus estimated rut depth for 10 all-terrain recreational vehicle (ATV) passes along the same track.

(a)

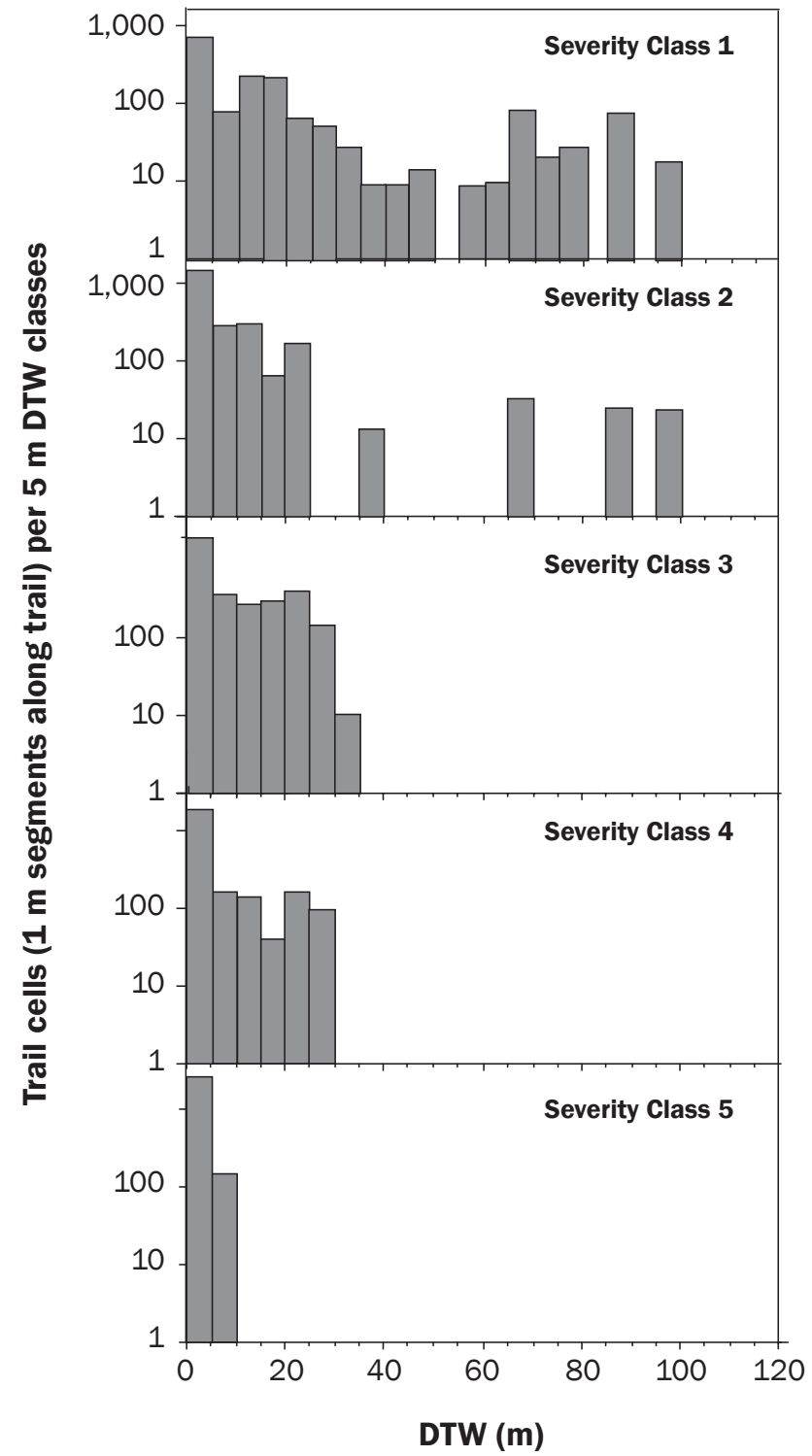

(b)

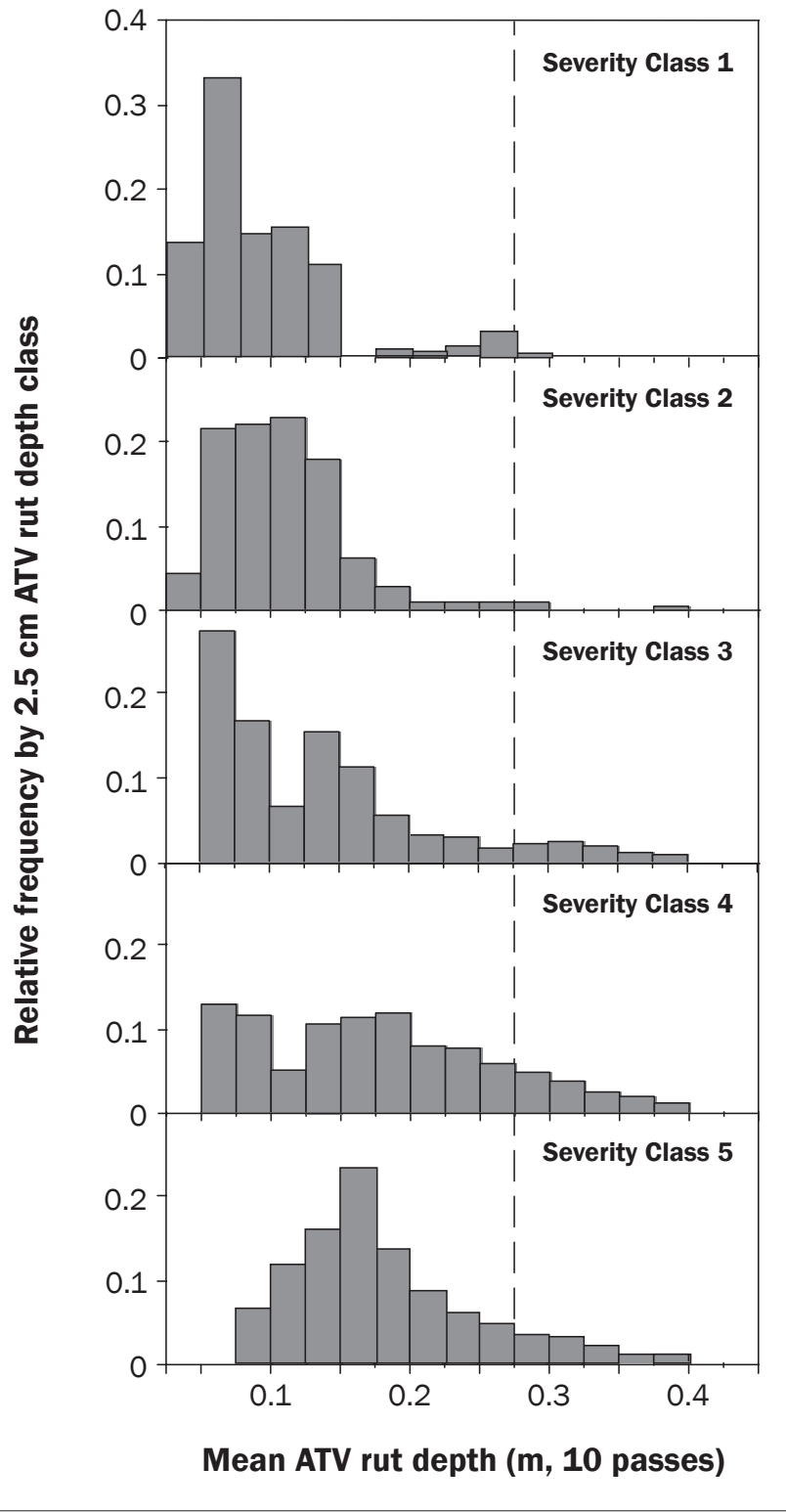

\section{References}

Agodzo, S., and I.Adama. 2003. Bulk density, cone index and water content relations for some Ghanian soils. In ICTP Lecture Notes Series, eds. D.M. Gabriels, G. Ghirardi, D.R. Nielsen, I Pla Sentis, and E. L. Skidmore. Volume XVIII. Trieste, Italy : The Abdus Salam International Centre for Theoretical Physics.

Balland, V., J. Pollacco, and P.A. Arp. 2008. Modeling soil hydraulic properties for a wide range of soil conditions. Ecological Modelling 219:300-316.

Bauer, P. 2003. Rutted and ruined: ATV damage on the Adirondack Forest Preserve. North Creek, New York: The Residents' Committee to Protect the Adirondacks. http://glorietamesa.org/ATVreport.pdf.
Bayrock, L.A. 1958. Appendix: Surface geology. In Exploratory Soil Survey of Alberta Map Sheets 84-D (north half), 84-E, 84-F, and 84-G, eds. J.D. Lindsay, S. Pawluk, and W. Odynsky. Prelimininary Soil Survey Report 59-1. Edmonton, Alberta: Research Council of Alberta.

Blouin,V.M., M.G. Schmidt, C.E. Bulmer, and M. Krzi. 2005. Mechanical disturbance impacts on soil properties and lodgepole pine growth in British Columbia's central interior. Canadian Journal of Soil Science 85:681-691.

Bruehler, G., and M. Sondergaard. 2004. GIS/GPS Trail Condition Inventories: A Virtual Toolbox for Trail Managers. Technical Report. UC Proceedings Abstract. Glennallen District, Alaska: US Department of Interior, Bureau of Land Management. http://proceedings.esri. com/library/userconf/proc04/docs/pap1590.pdf.
Carter, E.A., W.M. Aust, and J.A. Burger. 2007. Soil strength response of select soil disturbance classes on a wet pine flat in South Carolina. Forest Ecological Management 247:131-139.

Carter, E., T. McDonald, and J.Torber. 2000. Assessment of soil strength variability in a harvested loblolly pine plantation in the Piedmont region of Alabama, United States. New Zealand Journal of Forest Science 30:237-249.

Domsch, H., A. Ehlert, K. Giebel, and J. Boess. 2006. Evaluation of the soil penetration resistance along a transect to determine the loosening depth. Precision Agriculture 7:309-326.

Duckert, D., D. Morris, D. Deugo, S. Duckett, and S. McPherson. 2008. Developing site disturbance standards in Ontario: Linking science to forest policy within an 


\section{Figure 10}

Percentages distribution of the 5 trail damage severity classes along the $40 \mathrm{~km}$ trail within the Ghost River Forest Land Use Zone (GRFLUZ) area versus mapped rut depth (all-terrain recreational vehicle [ATV], 10 passes), also showing the frequency distribution of the no-damage class (severity class 0 ).

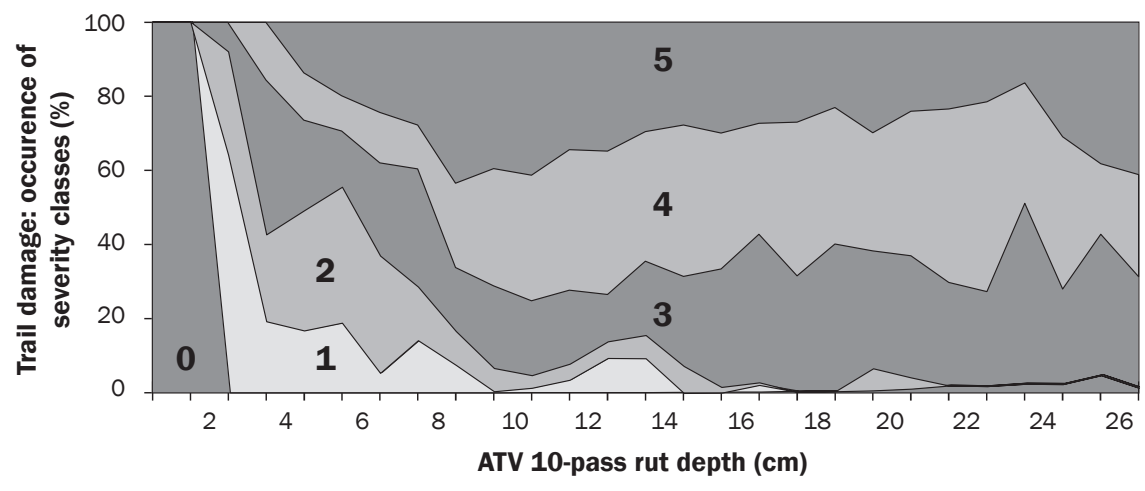

adaptive management framework. Canadian Journal of Soil Science 89:13-26.

Eliasson, L. 2005. Effects of forwarder tyre pressure on rut formation and soil compaction. Silva Fennica 39:549-557. EMEND (Ecosystem Management Emulating Natural Disturbance). 2012. EMEND Project. http://www. emend.rr.ualberta.ca/.

Foltz, R.B. 2006. Erosion from All Terrain Vehicle (ATV) trails on national forest lands. USDA Forest Service, Rocky Mountain Research Station, Moscow, ID. American Society of Agricultural and Biological Engineers Annual International Meeting, Portland, Oregon. http://forest.moscowfsl.wsu. edu/engr/library/Foltz/Foltz2006e/ASABE2006e.pdf.

Ghost River Alliance. 2011. An Assessment of the Cumulative Effects of Land Uses within the Ghost River Watershed, Alberta, Canada. Cochrane, Alberta: Ghost Watershed Alliance. http://www.ghostwatershed.ca/ GWAS/Research_\&_Data_files/2011\%20Ghost\%20 Report-web_1.pdf.

Grenier, J. 2008. Geosynthetics for trails in wet areas: 2008 Edition. 2300-Recreation 0823-2813-MTDC. Washington, DC: United States Department of Agriculture Forest Service Technology \& Development Program. http://atfiles.org/files/pdf/ohvbibliogVT00.pdf.

GRFLUZ (Ghost River Forest Land Use Zone). 2012 Ghost Public Land Use Zone. http://www.srd.alberta. ca/RecreationPublicUse/RecreationOnPublicLand/ PublicLand UseZones/documents / GhostPLUZBrochureMap-May11-2012.pdf.

Horn, R. 2004. Time dependence of soil mechanical properties and pore functions for arable soils. Soil Science Society of America Journal 68:1131-1137.

Kishchuk, B.E. 2004. Soils of the Ecosystem Management Emulating Natural Disturbance (EMEND) experimental area, northwestern Alberta. Inf. Rep. NOR-X-397. Edmonton, Alberta: Natural Resources Canada, Canadian Forest Service, Northern Forestry Centre.

Landsberg, J., R. Miller, H. Anderson, and J.Tepp. 2003. Bulk density and sol resistance to penetration as affected by commercial thinning in north eastern Washington. Research Paper PNW-RP-551. Portland, OR: USDA Forest Service, Pacific Northwest Research Station.

Marion, J.L., and N. Olive. 2006. Assessing and understanding trail degradation: Results from Big South Fork National
River and Recreational Area. Reston,VA: United States Department of the Interior. US Geological Survey. Patuxent Wildlife Research Center. Virginia Tech Field Unit. National Park Service. Final Research Report. http://www.parks.ca.gov/pages/1324/files/f10602\%20 marion\&olive.pdf.

McKeague, J.A. 1978. Manual on Soil Sampling and Methods of Analysis, 2nd edition. Pinawa, Manitoba: Canadian Society of Soil Science.

McNabb, D., and R. Campbell. 1985. Quantifying the impacts of forestry activities on soil productivity. In Foresters' Future: Leaders or Followers? Fort Collins, CO: Proceedings of the 1985 SAF National Convention.

Miller, R.E., J.D. McIver, S.W. Howes, and W.B. Gaeuman. 2010. Assessment of soil disturbance in forests of the Interior Columbia River Basin: A critique. General Technical Report PNW-GTR-811. Portland, OR: USDA Forest Service. Pacific Northwest Research Station. http://www. fs.fed.us/pnw/pubs/pnw_gtr811.pdf.

Murphy, P.N.C., J. Ogilvie, and P.A. Arp. 2009. Topographic modeling of soil moisture conditions: A comparison and verification of two models. European Journal of Soil Science 60:94-109.

Murphy, P.N.C., J. Ogilvie, F. Meng, B. White, J. Bhatti, and P.A. Arp. 2011. Modeling and mapping topographic variations in forest soils at high resolution: A case study. Ecological Modelling 222:2314-2332.

Naghdi, R., I. Bagheri, M. Lotfalian, and B. Setodeh. 2009 Rutting and soil displacement caused by 450C Timber Jack wheeled skidder (Asalem forest northern Iran). Journal of Forest Science 55:177-183.

Nearing, M., and L. West. 1988. Soil strength indices as indicators of consolidation. Transactions of the American Society of Agricultural Engineers 31:471-476.

Priddy, J.D., and W.E. Willoughby. 2006. Clarification of vehicle cone index with reference to mean maximum pressure. Journal of Terramechanics 43:85-96

Rab, M.A, FJ. Bradshaw, R.G. Campbell, and S. Murphy. 2005. Review of factors affecting disturbance, compaction and trafficability of soils with reference to timber harvesting in the forests of south-west Western Australia. Consultants Department of Conservation and Land Management, Western Australia, Sustainable Forest Management Series, SFM Technical Report
No. 2. Kensington, Western Australia: Department of Conservation and Land Management.

Raper, R.L. 2005.Agricultural traffic impacts on soil. Journal of Terramechanics 42:259-280.

Riedel, M.S. 2006. Quantifying trail erosion and stream sedimentation with sediment tracers. In Second interagency conference on research in the wetlands, ed. D.L. Fowler. Otto, NC: USDA Forest Service, Southern Research Station, Coweeta Hydrologic Laboratory, http://www.srs.fs.usda.gov/pubs/ja/ja_riedel001.pdf.

Rooney, T. 2008. Distribution of ecologically invasive plants along off road vehicle trails in the Chequeamegon National Forest, Wisconsin. The Michigan Botanist 44:178.

Saarilahti, M. 2002. Soil interaction model. In ECOWOOD studies made at the University of Helsinki, eds. R. Haarlaa and J. Salo. University of Helsinki, Faculty of Agriculture and Forestry, Department of Forest Resource Management. Publication 31, February 2003; 2002. http://ethesis.helsinki.fi/julkaisut/maa/mvaro/ publications/31/soilinte.pdf.

Saarilahti, M., and T. Anttila. 1999. Rut depth model for timber transport on moraine soils. Proceedings of the 9th International Conference of International Society for TerrainVehicle Systems, 14 -17. Sept. 1999, Munich, Germany.

Sakai, H.,T. Nordfjelll, K. Suadicani, B.Talbot, and E. Bollehus 2008. Soil compaction on forest soils from different kinds of tires and tracks and possibility of accurate estimate. Croatian Journal of Forest Engineering 29:1-27

Stokowski, P.A., and B. LaPointe. 2000. Environmental and social effects of ATVs and ORVs: An annotated bibliography and research assessment. School of Natural Resources, University of Vermont, Burlington. http:// atfiles.org/files/pdf/ohvbibliogVT00.pdf.

Vega-Nieva, D.J., P.N.C. Murphy, M. Castonguay, J. Ogilvie, and P.A. Arp. 2009. A modular terrain model for daily variations in machine-specific forest soil trafficability. Canadian Journal of Soil Science 89:93-109.

White, B., J. Ogilvie, D.M.H. Campbell, D. Hiltz, B. Gauthier, H.K. Chisholm, H.K.Wen, P.N.C. Murphy, and P.A.Arp. 2012. Using the cartographic depth-to-water indext to locate small streams and associated wet areas across landscapes. Canadian Water Resources Journal 37:333347, doi:10.4296/cwrj2011-909.

Wilkerson, E., and A.A Whitman. 2009. Recreation Trail Scorecard for Evaluating Trails in Northern New England. Science Note, NCI 2009-01, Brunswick, ME: Manomet Center for Conservation Sciences, Natural Capital Initiative. http://www.manomet.org/sites/ manomet.org/files/trailassessement_ncnote12.2009.pdf.

Wilson, J.P., and J.P. Seney. 1994. Erosional impact of hikers, horses, motorcycles, and off-road bicycles on mountain trails in Montana. International Mountain Society. Mountain Research and Development 14:77-88.

Wronski, E.B., D. Stodart, and N. Humphreys. 1990. Trafficability assessment as an aid to planning logging operations. Appita Journal 43:18-22.

Zenner, E.K. J.T. Fauskee, A.L. Berger, and K.J. Puettmann. 2007. Impacts of skidding traffic intensity on soil disturbance, soil recovery, and aspen regeneration in North Central Minnesota. Northern Journal of Applied Forestry 24. 